NBSIR 88-3094

FIBROUS ALUMINA-SILICA

INSULATION BOARD

AS A CANDIDATE

STANDARD REFERENCE MATERIAL

OF THERMAL RESISTANCE

Jerome G. Hust

David R. Smith

National Bureau of Standards

U.S. Department of Commerce

Boulder, Colorado 80303-3328

June 1988

$-Q C$

100

.456

\#88-3094

1988

C.2

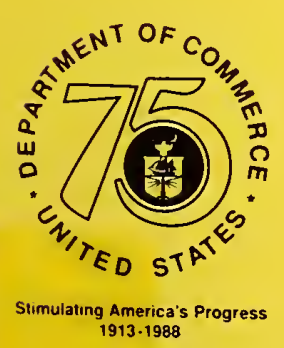





\section{Jerome G. Hust \\ David R. Smith}

Chemical Engineering Science Division

Center for Chemical Engineering

National Bureau of Standards

U.S. Department of Commerce

Boulder, Colorado 80303-3328

June 1988

Sponsored, in part, by

U.S. Department of Energy

Oak Ridge National Laboratory

Oak Ridge, Tennessee 37830

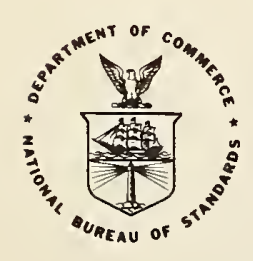

U.S. DEPARTMENT OF COMMERCE, C. William Verity, Secretary 



\section{CONTENTS}

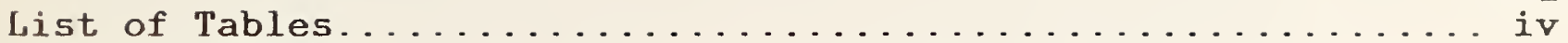

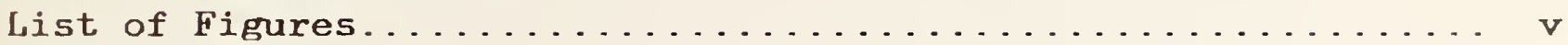

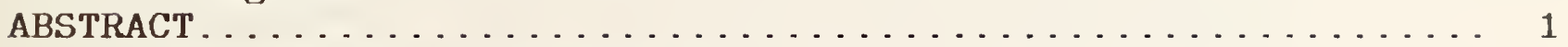

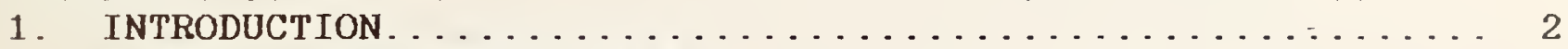

2. MATERIAL CHARACTERIZATION . . . . . . . . . . . . . . . . . . 2

3. MEASUREMENTS . . . . . . . . . . . . . . . . . . . . . . . . . 2

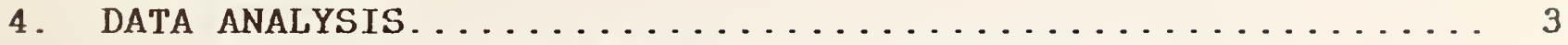

A. Conductivity as a Function of Temperature............ 4

B. Conductivity as a Function of Density............... 5

C. Conductivity as a Function of Pressure............... 6

D. Conductivity as a Function of Environmental Gas........ 7

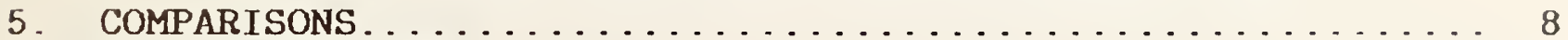

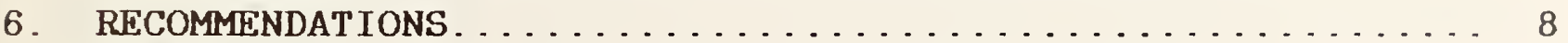

7. REFERENCES . . . . . . . . . . . . . . . . . . . . . . . . 9 


\section{LIST OF TABLES}

Table 1. Thermal conductivity of one pair of fibrous aluminasilica insulation board with a density of $259 \mathrm{~kg} / \mathrm{m}^{3}$, at mean temperatures of 93 to $311 \mathrm{~K}$. Measurements were performed in dry nitrogen gas at a pressure of $83 \mathrm{kPa}$ (623 Torr) using the NBS low-temperature guarded hot plate..................... 10

Table 2. Thermal conductivity of eight specimens of fibrous alumina-silica insulation board with densities of 236 to $249 \mathrm{~kg} / \mathrm{m}^{3}$, at mean temperatures of 313 to $746 \mathrm{~K}$. Measurements were performed in air at 83 $\mathrm{kPa}$ (623 Torr), using the NBS high-temperature

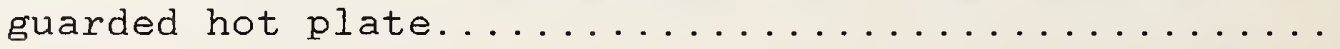

Table 3. Thermal conductivity of a selected pair of fibrous alumina-silica insulation boards with densities of 236 to $249 \mathrm{~kg} / \mathrm{m}^{3}$, at mean temperatures of 313 and $693 \mathrm{~K}$. Measurements were performed in air at pressures from 84 to $0.0047 \mathrm{kPa}$, using the NBS high-

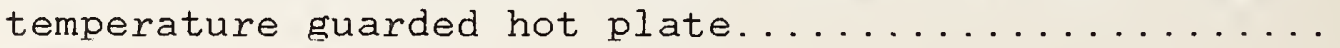

Table 4. Thermal conductivity of the selected pair of fibrous alumina-silica insulation board with a density of $247 \mathrm{~kg} / \mathrm{m}^{3}$, at mean temperatures of 313 to $692 \mathrm{~K}$. Measurements were performed in helium gas at pressures from 84 to $87 \mathrm{kPa}$ (630 to 650 Torr), using the NBS high-temperature guarded hot plate...........

Table 5a. Thermal conductivity of eight different specimens of fibrous alumina-silica insulation board with densities of 236 to $249 \mathrm{~kg} / \mathrm{m}^{3}$, at a mean temperature of $313 \mathrm{~K}$. Measurements were performed in air at $84 \mathrm{kPa}$ using the NBS high-temperature

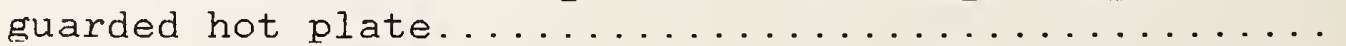

Table 5b. Thermal conductivity of fibrous alumina-silica insulation board (round-robin material) with densities of 207 to $308 \mathrm{~kg} / \mathrm{m}^{3}$, at a mean temperature of $313 \mathrm{~K}$. Measurements were performed in air at $84 \mathrm{kPa}$ using the NBS high-temperature guarded hot plate... 


\section{LIST OF FIGURES}

Figure 1. Thermal conductivity of a pair of fibrous aluminaPage silica insulation boards as measured by NBS/B, at mean temperatures of 93 to $311 \mathrm{~K}$ and at ambient atmospheric pressure of $83 \mathrm{kPa}$. Boards have a density of $259 \mathrm{~kg} / \mathrm{m} 3$. The solid line was calculated from eq(1)...................... 15

Figure 2. Deviations of the NBS low-temperature thermal conductivity data from eq(1)................

Figure 3. Thermal conductivity of a pair of fibrous aluminasilica insulation boards as measured by NBS/B, at mean temperatures of 313 to $746 \mathrm{~K}$ and at ambient atmospheric pressure of $83 \mathrm{kPa}$. Boards have a density of $247 \mathrm{~kg} / \mathrm{m} 3$. The solid line was calculated

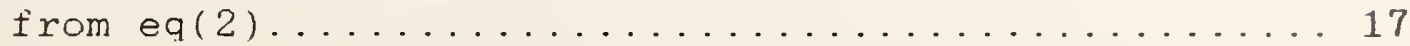

Figure 4. Deviations of the NBS high-temperature thermal con-

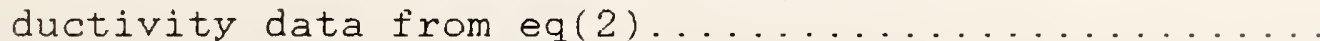

Figure 5. Thermal conductivity of fibrous alumina-silica insulation boards as measured by NBS/B, at a mean temperature of $333 \mathrm{~K}$ and at ambient atmospheric pressure of $84 \mathrm{kPa}$. The solid line was calculated

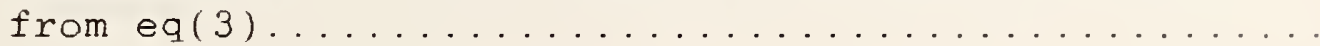

Figure 6. Deviations of the NES thermal conductivity data

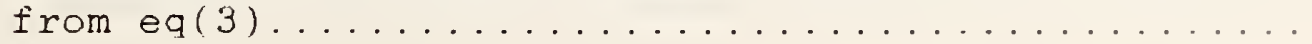

Figure 7. Thermal conductivity of fibrous alumina-silica insulation boards as measured by NBS/B, at a mean temperature of $313 \mathrm{~K}$. The boards have a density of $247 \mathrm{~kg} / \mathrm{m} 3$. The solid line was calculated from eq(4) with $k_{0}=5.75, \quad A=778, \quad P_{0}=0.054 \mathrm{kPa}$

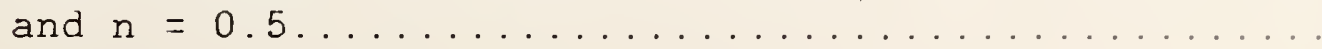

Figure 8. Deviations of the NBS thermal conductivity data

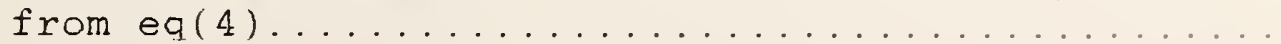


Figure 9. Thermal conductivity of fibrous alumina-silica insulation boards as measured by NBS/B, in an environment of ure helium gas. The board density is $247 \mathrm{~kg} / \mathrm{m} 3$. The solid line was calculated from

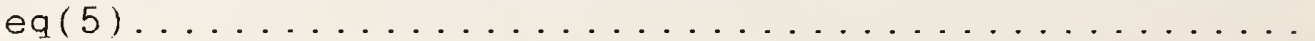

Figure 10. Round-robin measurements, by seven participating labs including NBS/B, of thermal conductivity of fibrous alumina-silica insulation boards, at the local ambient atmospheric pressure of each participating laboratory. The board density is $238 \mathrm{~kg} / \mathrm{m} 3$. The solid line is calculated from

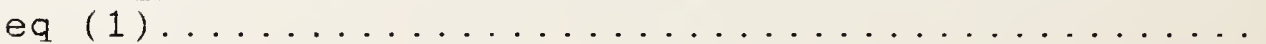

Figure 11. Thermal conductivity of fibrous alumina-silica insulation boards, as measured by the producer (solid line) at a pressure of $84 \mathrm{kPa}$, for a board with a density of $244 \mathrm{~kg} / \mathrm{m} 3$. The solid line is given by eq(6). Data points shown are NBS data for a different specimen with a density

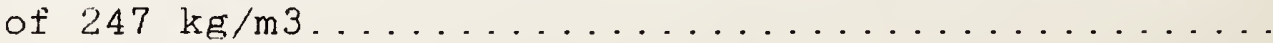

Figure 12. Deviations of the NBS/B thermal conductivity data

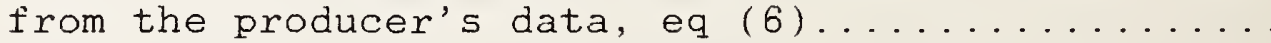




\title{
Fibrous Alumina-Silica Insulation Board as a Candidate Standard Reference Material \\ of Thermal Resistance
}

\author{
Jerome G. Hust \\ and \\ David R. Smith \\ Center for Chemical Engineering \\ National Engineering Laboratory \\ National Bureau of Standards \\ Boulder, CO 80303-3328
}

Measurements of apparent thermal conductivity are reported in order to provide the basis for certifying fibrous alumina-silica insulation board as a Standard Reference Material (SRM) of thermal resistance. These data encompass ranges of temperature from 93 to $746 \mathrm{~K}$, densities from 207 to $308 \mathrm{~kg} / \mathrm{m}^{3}$, and fill-gas pressures from roughing-pump vacuum to atmospheric pressure, in environments of both air and helium. Detailed analyses and intercomparisons of previously published data are given.

Key words: alumina-silica board; apparent thermal conductivity; density; pressure; Standard Reference Material; temperature: thermal insulation; thermal resistance.

This work was funded in part by DOE/ORNL under contract ORNL/IA21428 . 


\section{INTRODUCTION}

The Office of Standard Reference Materials (OSRM) of the U.S. National Bureau of Standards (NBS) establishes Standard Reference Materials (SRMs) needed to improve reliability in measurement of physical properties. The Properties of Solids Group within the Center for Chemical Engineering (CCE) has actively participated for about 25 years in the effort to establish SRMs of thermal resistance over a broad range of conductivities and temperatures. The status of this work has been summarized by Hust [1].

During the mid-1970's, Committee C-16 of the American Society for Testing and Materials recognized the great need for SRMs of thermal insulation. As a consequence, a task-group was established under the auspices of ASTM Subcommittee C16.30 on thermal measurements. Recommendations for establishing thermal insulation SRMs were published in 1978 [2].

Clay-bonded fibrous alumina-silica insulation is being investigated for possible use as a high-temperature SRM of thermal resistance. We report measurements of the apparent thermal conductivity of several specimens of this material using two different guardedhot-plate apparatus (GHP). The low-temperature GHP obtained data over a range of mean specimen temperature from 93 to $311 \mathrm{~K}$; the high-temperature GHP covered the range of mean temperatures from 313 to $746 \mathrm{~K}$. At the present time no SRM of thermal resistance for temperatures above $330 \mathrm{~K}$ is available from OSRM, in spite of the strong need for such SRMs.

\section{MATERIAL CHARACTERIZATION}

The material studied is produced as rigid boards from claybonded fibers of alumina-silica. The specimens obtained from the producer are nominally $2.5 \mathrm{~cm}$ ( 1 in) thick and about $30 \mathrm{~cm}$ (1 f) square. The alumina-silica fibers are oriented approximately parallel to the faces of the boards. The bulk densities of the specimens ranged from 207 to $308 \mathrm{~kg} / \mathrm{m}^{3}$.

This material was investigated because of the recommendations of the ASTM C16.30 task-group. The producer of this material had decided to establish it as an in-house standard and to cooperate with us by providing carefully selected specimens for determining the suitability of the material as an SRM. 


\section{MEASUREMENTS}

For brevity we shall use the term "thermal conductivity" to denote "apparent thermal conductivity" in the following text. Analysis of our data in the following section suggests that radiative and convective heat transfer in this fibrous alumina-silica board contribute only a small amount in comparison to conductive heat transfer. "Thermal conductivity" seems to be a valid descriptor of the heat-transfer behavior of this material.

Thermal conductivity data reported here were obtained with the high-temperature GHP, described by Hust, Filla, Hurley, and Smith $[3,4]$, and with the low-temperature GHP, described by Smith, Hust, and Van Poolen [5]. The diameters of the circular stack and metered main heater areas are respectively 20 and $10 \mathrm{~cm}$ for the low-temperature GHP, and are 25 and $12.5 \mathrm{~cm}$ for the high-temperature GHP.

Thermal conductivity at low temperatures was measured in dry nitrogen gas at atmospheric pressure ( $83 \mathrm{kPa} ; 623$ Torr), for a single pair of specimens whose mean bulk density was $259 \mathrm{~kg} / \mathrm{m}^{3}$. Table 1 lists the thermal conductivity measurements on this pair under the two-sided mode of operation of the low-temperature GHP, at mean temperatures ranging from 93 to $311 \mathrm{~K}(-180$ to $+380 \mathrm{C})$.

Measurements of thermal conductivity at high temperatures were performed initially on an additional set of eight carefully selected specimens in an atmosphere of air at ambient pressure, $83 \mathrm{kPa}$. Each specimen was individually measured in the single-sided mode of operation of the high-temperature GHP to determine the variability of thermal conductivity within the set. The first block of data in table 2 lists thermal conductivity data for a mean temperature of $313 \mathrm{~K}$. Because multiple measurements were made on some of the specimens there are more than eight data points in this first block.

From the set of eight specimens we selected two, matched in density; this matched pair was then measured in air at 83 kPa, at mean temperatures ranging from 313 to $746 \mathrm{~K}$ (second block of table 2). In addition, the thermal conductivity of this pair was measured at various air pressures from ambient to low vacuum. Table 3 gives the data at mean temperatures of 313 and $693 \mathrm{~K}$ and for various pressures ranging from 83.6 to $0.0047 \mathrm{kPa}$ (0.035 Torr).

Thermal conductivity of this matched pair was also measured in an environment of helium gas at 84 to $87 \mathrm{kPa}$ at five different mean temperatures from 313 to $692 \mathrm{~K}$ (table 4). The variation in pressure was due to the rise in temperature of the sealed system.

Because the bulk densities of the group of eight specimens cov ered only a very small range (see table 5a), four additional specimens were obtained with appreciably different bulk densities. These specimens were individually measured in the single-sided mode to determine how the thermal conductivity depends on density. Finally. measurements were included from a study of thirteen more specimens 
which were used in a high-temperature interlaboratory comparison [6]. The results of single-sided thermal conductivity measurements on all the additional seventeen specimens, at mean temperatures of $333 \mathrm{~K}$, are also presented here (table 5b) to aid in assessing specimen variability and dependence on density. All these measurements were conducted in air at $84 \mathrm{kPa}$. Multiple measurements performed on some of the specimens are responsible for the presence of more data points in tables $5 \mathrm{a}$ and $5 \mathrm{~b}$ than the number of specimens.

\section{DATA ANALYSIS}

The data were analyzed to determine the dependence of thermal conductivity on temperature, density, and environmental gas pressure and species.

A. Conductivity as a Function of Temperature.

The first matched pair of specimens, measured in dry nitrogen gas at $83 \mathrm{kPa}$ (623 Torr) in the low-temperature apparatus, had a mean density of $259 \mathrm{~kg} / \mathrm{m}^{3}$. The temperature dependence of thermal conductivity for temperatures from 93 to $311 \mathrm{~K}$ was represented by

$$
k(T)=6.932+0.1769 \cdot T-0.3070 \times 10-6 \cdot T^{3},
$$

where $\mathrm{k}$ is in $\mathrm{mW} /(\mathrm{m} \cdot \mathrm{K})$ and $\mathrm{T}$ is in $\mathrm{K}$. This correlation was obtained using the thermal conductivity integral method [7] and a weighted least-squares fit, as were all the correlations obtained in the following analysis. The weighting gives approximately equal percentage deviations, to reflect the usual experimental practice of holding the relative error of the measurements constant. The data used to determine this correlation, along with values calculated from it, are listed in table 1 and illustrated in figure 1. Deviations of the data from eq(1) are shown in figure 2.

The dependence of thermal conductivity on temperature for a different matched pair of specimens, each having a density of about $247 \mathrm{~kg} / \mathrm{m}^{3}$, and measured in air at atmospheric pressure in the hightemperature apparatus, was represented by

$$
k(T)=15.12+0.09489 \cdot T+2.888 \times 10^{-8} \cdot T^{3}
$$

where $\mathrm{k}$ is in $\mathrm{mW} /(\mathrm{m} \cdot \mathrm{K})$ and $\mathrm{T}$ is in $\mathrm{K}$. This correlation is valid for mean temperatures from 313 to $746 \mathrm{~K}$ and for specimens in air at 83 $\mathrm{kPa}$. The data used to determine this relation are listed in table 2 and illustrated in figure 3. The deviations of the data from eq(2) are illustrated in figure 4. 
The very small positive value of the coefficient of the T3 term in eq(2) correlates with the slight upward curvature evident in figure 3. At $\mathrm{T}=310 \mathrm{~K}$ the $\mathrm{T}^{3}$ term contributes $0.86 \mathrm{~mW} /(\mathrm{m} \cdot \mathrm{K})$ to the total thermal conductivity value of $45.4 \mathrm{~mW} /(\mathrm{m} \cdot \mathrm{K})$, or only $2 \%$. At the upper temperature limit of this study, $750 \mathrm{~K}$, the $\mathrm{T}^{3}$ term represents $12 \%$ of the total thermal conductivity. On theoretical grounds the physical origin of this relatively small $\mathrm{T}^{3}$ term in the $k(T)$ function is probably radiative heat transfer. The material is dense enough that convective heat transfer is negligible at room temperature. Thus conductive heat transfer through the solid fibers and through the environmental gas (air) between the fibers is the major contributor to the total heat transfer.

At a typical temperature of $312 \mathrm{~K}$, eq(1) yields a thermal conductivity of $52.8 \mathrm{~mW} /(\mathrm{m} \cdot \mathrm{K})$ for one pair, while eq(2) yields 45.6 $\mathrm{mW} /(\mathrm{m} \cdot \mathrm{K})$ for the other pair, a difference of $14 \%$. The low-temperature and the high-temperature apparatus each have an estimated accuracy of $2 \%$ at $312 \mathrm{~K}$, and the experimental repeatability for removal and re-installation of specimens is about $0.5 \%$ for each apparatus. The dependence of the thermal conductivity on density is not known very precisely, as will be discussed in the next two paragraphs. It is quite possible that differences in density between the two pairs are responsible for the lack of agreement in the values of $\mathrm{k}$ at the same temperature. The second pair was manufactured several years after the first pair, and was measured 6 years later.

B. Conductivity as a Function of Density

The data used to determine the dependence of thermal conductivity on density are illustrated in figure 5 and listed in table $5 \mathrm{~b}$. The dependence of thermal conductivity on density for specimens at a temperature of $333 \mathrm{~K}$ and in air at $83 \mathrm{kPa}$ was represented by

$$
k(D)=42 .+0.033 . D \text {, }
$$

where $k(D)$ is in $\mathrm{mW} /(\mathrm{m} \cdot \mathrm{K})$ and $D$ is in $\mathrm{kg} / \mathrm{m}^{3}$. This correlation is valid for a range of densities from 207 to $308 \mathrm{~kg} / \mathrm{m}^{3}$.

The large scatter of data in this figure $( \pm 8 \%$ at the low end of the curve) shows that unknown factors are present. Some of these specimens, used in the round-robin study, were not as carefully selected as the specimens selected as candidates for SRM certification. The imprecision caused by the measurement process is thought to be less than $1 \%$. As a consequence of the large scatter, the correlation with density is highly uncertain. The deviations of the data from eq(3) are illustrated in figure 6. The relatively larpe deviations, and concomitant large uncertainty in the k(U) correlation, are attributed to specimen variations of unknown origin. 


\section{Conductivity as a Function of Pressure}

The dependence of thermal conductivity on pressure for specimens at a temperature of $313 \mathrm{~K}$ and having a density of $247 \mathrm{~kg} / \mathrm{m}^{3}$ was represented by

$$
k(P)=k 0+\frac{A \cdot P}{\left(1+[P / P 0]^{n}\right) 1 / n},
$$

where $k$ and $k o$ are in $\mathrm{mW} /(\mathrm{m} \cdot \mathrm{K})$, and $\mathrm{P}$ is in $\mathrm{kPa}$; $\mathrm{ko}$ and $\mathrm{A}$ are constants. Po is a pressure parameter which determines the location of the transition region where $k$ rises rapidly with increasing $P$. The parameter ko models the constant value approached by $k$ at very low values of $\mathrm{P}\left(\mathrm{P}<\mathrm{P}_{0}\right)$. Thus the value of ko represents conduction by the solid fiber matrix. This contribution is independent of gas pressure and is what remains at zero pressure. To match the observed behavior $k$ also approaches a different constant, ko + A. Po, at high values of $P\left(P>>P_{0}\right)$. At $P=P_{0}, k\left(P_{0}\right)=k_{0}+A \cdot P_{0} / 2(1 / n)$.

Values of ko and A were obtained by an unweighted least squares fit with $n$ and Po chosen by trial and error to yield the minimum standard deviation of the fit. In performing this fit it was found that, for the somewhat limited range of pressure for which we obtained data, the minimum standard deviation of the fit (1.26) is relatively insensitive to the values of $\mathrm{n}$ and Po. Thus for simplicity we forced $n=0.5(1 / \mathrm{n}=2)$ and then found ko $=5.75 \mathrm{~mW} /(\mathrm{m} \cdot \mathrm{K})$, $A=778$, and $P_{0}=0.054 \mathrm{kPa}(0.40$ Torr), with a resulting standard deviation of 1.34 , very close to the global minimum.

The data used to determine this dependence on air pressure, along with the smooth curve calculated from eq(4), are listed in table 3 and shown in figure 7. Deviations of the data from eq(4) are illustrated in figure 8. The relatively large variations exhibited at low pressures are attributed to large relative uncertainties in the measurement and control of the air pressure.

This pressure dependence of $k$ indicates a reduction of $-0.9 \%$ in thermal conductivity in the value at the $1650 \mathrm{~m}$ ( $5400 \mathrm{ft}$ ) elevation of our laboratory at Boulder, Colorado, in comparison to the value at sea level.

Using kinetic theory we can also estimate, from the value of Po obtained above, the effective size of the pores in the material. The transition region, passing from the upper constant value to the lower constant value in the $k(P)$ correlation as the air pressure is reduced, should be found where the mean free path (mfp) of the air molecules becomes about equal to the pore size. In this region, the probability of a collision with another air molecule becomes approximately equal to the probability of a collision with a fiber of insulation material. Reference [8] derives a relation showing the 
mfp to be inversely proportional to pressure, and estimates the mfp of oxygen molecules to be about $8 \times 10^{-8} \mathrm{~m}$ at standard conditions $(101.3 \mathrm{kPa}$ and $273 \mathrm{~K})$. At $313 \mathrm{~K}$ and $0.054 \mathrm{kPa}(0.4$ Torr) the mfp of oxygen molecules is estimated to be $0.15 \mathrm{~mm}$. The atmosphere is composed of $20 \% \mathrm{O}_{2}$ and $79 \% \mathrm{~N} 2$; nitrogen has a molecular mass only $12 \%$ less than that of oxygen, so for our purposes the estimated mfp of air should be about the same as the estimate for oxygen. Thus the estimated pore size in the material is also about $0.15 \mathrm{~mm}$. We can see no pores larger than an upper limit of about $0.2 \mathrm{~mm}$.

D. Conductivity as a Function of Environmental Gas

The temperature dependence of thermal conductivity for the matched pair in an atmosphere of pure helium gas was represented by a relation similar in form to that used for the conductivity in air:

$$
\mathrm{kHe}=86.166+0.2940 \cdot \mathrm{T}-0.13783 \times 10^{-7} \cdot \mathrm{T}^{3}
$$

The data used to determine this correlation are listed in table 4 and plotted in figure 9. The standard deviation of the data from the solid curve is only $0.03 \%$.

At $293 \mathrm{~K}$ (200 C) pure helium gas at atmospheric pressure has a thermal conductivity of $147.1 \mathrm{~mW} /(\mathrm{m} \cdot \mathrm{K})$. For the fibrous aluminasilica insulation in pure helium gas at the same temperature and pressure, eq(5) gives a thermal conductivity value of $172.0 \mathrm{~mW} /(\mathrm{m} \cdot \mathrm{K})$ The pressure dependence of conductivity at low pressure suggested that $k_{0}=5.75 \mathrm{~mW} /(\mathrm{m} \cdot \mathrm{K})$ is the contribution to the thermal conductivity by the solid fiber matrix alone. The conductivity of the fiber matrix in helium is greater than that for pure helium alone by a difference of $24.9 \mathrm{~mW} /(\mathrm{m} \cdot \mathrm{K})$, which is significantly greater than ko

A similar comparison is possible using the corresponding data for air. For specimens in air at $293 \mathrm{~K}$ and atmospheric pressure, we used eq(2) as the correlation (by extrapolation) because this relation was obtained for data from the same high-temperature GHP used to obtain the helium correlation, eq(5). Eq(2) gives a value of $43.7 \mathrm{~mW} /(\mathrm{m} \cdot \mathrm{K})$ for the thermal conductivity. At the same temperature and pressure pure air has a conductivity of $25.1 \mathrm{~mW} /(\mathrm{m} \cdot \mathrm{K})$. The conductivity of the fiber matrix in air is greater than the conductivity of pure air alone by a difference of $18.6 \mathrm{~mW} /(\mathrm{m} \cdot \mathrm{K})$, which again exceeds the conductivity of the fiber matrix alone, and by approximately the same magnitude as the difference found for helium gas. This increase in conductivity between a pure gas and the same gas in the solid fiber matrix should depend on the density of the solid fibers, the porosity of the fiber matrix, and on the conductivities of the solid fibers and of the environmental gas. Analysis of the interaction between the environmental gas and solid fiber matrix will be left as the subject of a separate paper. 


\section{COMPARISONS}

The high-temperature results obtained by this investigation can be compared to two other sources of thermal conductivity data: (a) the results [6] of a recently completed round robin sponsored by ASTM Committee C 16.30, and, (b) data published [9] by the producer of this material. The round-robin data, for a set of specimens having a mean density of $238 \mathrm{~kg} / \mathrm{m}^{3}$, are compared to eq(1) in figure 10. The results reported here lie within the band of measurements reported by the round robin participants. The effect of variation in density for the round-robin specimens is known [6] to be negligible here.

The high-temperature measurements reported by the producer, using five different apparatus, are compared in figure 11 . The spread of the results from these five apparatus was reported to be 10\%. A least-squares fit to the producer's data gave the relation

$$
k(T)=14.2+0.0916 \mathrm{~T}+2.776 \times 10-8 \mathrm{~T}^{3}
$$

which is plotted as the solid line in figure 11. The standard deviation of eq(5) from the NBS data (circles in figure 12) for the SRM candidate material is $-4.4 \%$, well within the $10 \%$ spread of the results found by the producer. Visually the line appears to be parallel to the data points, showing the deviation to be systematic.

\section{RECOMMENDATIONS}

Measurements of the thermal conductivity of the eight specimens carefully selected for possible use as an SRM reveal a low variability for this material. This suggests that this material can be supplied with a sufficiently small variability to serve as an excellent SRM. However, the specimens used in the round robin study exhibited a much larger variability. If a large lot of this material (100 to 200 specimens) can be obtained with a variability similar to that of the originally supplied ten specimens, this material would be recommended for use as an SRM. If on the other hand the larger variability is more typical of this material, each specimen would need to be individually measured by NBS to be useful, and would then be certified individually as calibrated transfer specimens. 


\section{REFERENCES}

[1] Hust, J.G. "Status of Thermal Conductivity Standard Reference Materials at the National Bureau of Standards", Thermal Conductivity 18, Proceedings of the 18th International Conference on Thermal Conductivity; Ashworth, T., and Smith, David R., Eds.; pp. 327-338 (Plenum, New York, 1985).

[2] ASTM Subcommittee C16.30, "Reference Materials for Insulation Measurement Comparisons", Thermal Transmission Measurements of Insulation, ASTM STP 660, Tye, R.P., Ed., pp. 7-29 (ASTM, Philadelphia, 1978 ).

[3] Hust, J.G., Filla, B.J., Hurley, J.A. and Smith, David R., "An Automated High Temperature Guarded-Hot-Plate Apparatus for Measuring Thermal Conductivity", NBSIR 87-3089, (U.S. National Bureau of Standards, May 1988).

[4] Hust, J.G., Filla, B.J., Hurley, J.A. and Smith, David R., "An Automated High Temperature Guarded-Hot-Plate Apparatus for Measuring Thermal Conductivity of Insulations Between 300 and $750 \mathrm{~K}$ ", to be published in Proceedings of ASTM "Symposium on Thermal Insulation, Materials and Systems", STP 922 (1988).

[5] Smith, David R., Hust, J.G., and Van Poolen, L.J. "A GuardedHot-Plate Apparatus for Measuring Effective Thermal Conductivity of Insulations Between $80 \mathrm{~K}$ and $360 \mathrm{~K}$ ", NBSIR 81-1657, (U.S. National Bureau of Standards, 1982).

[6] Hust, J.G. and Smith, David R., "Round-Robin Measurements of the Apparent Thermal Conductivity of Two Refractory Insulation Materials, Using High-Temperature Guarded-Hot-Plate Apparatus", NBSIR 88-3087, (U.S. National Bureau of Standards, April 1988).

[7] Hust, J.G. and Lankford, A.B., "Comments on the Measurement of Thermal Conductivity and Presentation of a Thermal Conductivity Integral Method", Int. J. of Thermophysics 3/1, 67-77, (Oct. 1982).

[8] Sears, Francis W., Thermodynamics, 2nd Ed. (Addison-Wesley, Reading, Mass. 1959), p. 257.

[9] Mitchell, H., "The Development of a Refractory Fiber Insulation for Use as a High Temperature Thermal Transmission Calibration Sample", Thermal Conductivity 19, Proceedings of the 19th International Thermal Conductivity Conference; Yarbrough, D., ed. (Plenum, New York, 1988). 
Toble 1. Thermal conductivity of one poir of fibrous alumino-silica insulation boord with o density of $259 \mathrm{~kg} / \mathrm{m}^{3}$, ot meon temperotures of 93 to $311 \mathrm{~K}$. Meosurements were performed in dry nitrogen gos ot o pressure of $83 \mathrm{kPo}$ (623 Torr) using the NBS low-temperoture guorded hot plate.

\begin{tabular}{|c|c|c|c|c|c|c|c|}
\hline $\begin{array}{l}\text { Th i } \\
\text { (k) }\end{array}$ & $\begin{array}{l}\text { Tlo } \\
\text { (K) }\end{array}$ & $\begin{array}{c}\text { Tmeon } \\
(\mathrm{K})\end{array}$ & $\begin{array}{c}K d a t \\
m W /(m \cdot K)\end{array}$ & $\begin{array}{l}\text { AREA } \\
\left(\mathrm{cm}^{2}\right)\end{array}$ & $\begin{array}{l}\text { DELX } \\
(\mathrm{cm})\end{array}$ & $\begin{array}{l}\text { DENSITY } \\
\left(\mathrm{kg} / \mathrm{m}^{3}\right)\end{array}$ & $\begin{array}{l}\text { PRESSURE } \\
(k P o)\end{array}$ \\
\hline 17.292 & 121.818 & 134.555 & 30.43 & 83.1 & 2.531 & 259.60 & $.826 E+02$ \\
\hline 59. & 134 & 147.266 & 32.19 & 83.2 & 2.53 & 259.50 & $E+02$ \\
\hline 172.069 & 146.907 & 159.488 & 34.02 & 83.2 & 2.531 & 259.50 & 02 \\
\hline 185.824 & 159.714 & 172.369 & 35.88 & 83.3 & 2.5 & 259.50 & 02 \\
\hline 266 & 80.793 & 93.530 & 22 & 83.0 & 2. & 259.70 & 02 \\
\hline 27.50 & 96.019 & 108.790 & 25.77 & 83 & 2. & .70 & 102 \\
\hline 34.15 & 108.346 & 121.250 & 28.13 & 83.1 & 2.530 & 259.60 & $.826 E+02$ \\
\hline 97.521 & 172.114 & 184.818 & 37.81 & 83.3 & 2.532 & 259.40 & $.826 E+02$ \\
\hline 210.219 & 184.973 & 197.596 & 39.44 & 83.3 & 2.533 & 259.40 & $.826 E+02$ \\
\hline 22.916 & 197.561 & 210.239 & 41.20 & 83.4 & 2.533 & 259.30 & $.826 E+02$ \\
\hline 235.513 & 210.235 & 222.874 & 42.49 & 83.4 & 2.533 & 259.30 & $.826 E+02$ \\
\hline 247.982 & 222.836 & 235.409 & 44.09 & 83.5 & 2.534 & 259.20 & $.826 E+02$ \\
\hline 247.96 & 222.829 & 235.398 & 44.85 & 83.5 & 2.534 & 259.20 & $.826 E+02$ \\
\hline 260.59 & 235.438 & 248.015 & 46.04 & 83.5 & 2.534 & 259.20 & $.826 E+02$ \\
\hline 273.21 & 247.996 & 260.606 & 47.70 & 83.6 & 2.535 & 259.20 & $.826 E+02$ \\
\hline 7 & 260.569 & 273.146 & 49.01 & 83.6 & 2.535 & 259.10 & $826 E+02$ \\
\hline & 273.177 & 285.743 & 49.89 & 83. & 2.536 & 259.10 & $.813 E+02$ \\
\hline & 285.65 & 298.278 & 51.65 & 83 & 2.536 & 259.00 & $826 E+02$ \\
\hline 23 & 298.310 & 310.852 & 53.1 & 83.8 & 2.537 & 259.00 & $826 E$ \\
\hline
\end{tabular}

Table 2. Thermal conductivity of eight specimens of fibrous aluminasilico insulation boord with densities of 236 to $249 \mathrm{~kg} / \mathrm{m}^{3}$. at mean temperatures of 313 to $746 \mathrm{~K}$. Measurements were performed in oir ot $83 \mathrm{kPa}$ (623 Torr), using the NBS hightemperature guarded hot plate.

\begin{tabular}{|c|c|c|c|c|c|c|c|}
\hline $\begin{array}{l}\text { Thi } \\
(\mathrm{K})\end{array}$ & $\begin{array}{l}\text { T lo } \\
(\mathrm{K})\end{array}$ & $\begin{array}{c}\text { Tmean } \\
(K)\end{array}$ & $\begin{array}{c}K d a t \\
m w /(m \cdot K)\end{array}$ & $\begin{array}{l}\text { AREA } \\
\left(\mathrm{cm}^{2}\right)\end{array}$ & $\begin{array}{l}\text { DELX } \\
(\mathrm{cm})\end{array}$ & $\begin{array}{l}\text { DENSITY } \\
\left(\mathrm{kg} / \mathrm{m}^{3}\right)\end{array}$ & $\begin{array}{l}\text { PRESSURE } \\
(\mathrm{kPo})\end{array}$ \\
\hline 42 & 303.114 & 313.078 & 45.44 & 128. & 2.537 & 242.70 & $836 E+02$ \\
\hline 23.050 & 303.127 & 89 & 4 & 1 & 2 . & 9.40 & \\
\hline 23.050 & 303.049 & 050 & 56 & 1 & 2. & 244.70 & 02 \\
\hline 23.024 & 303.095 & 313.060 & 45.29 & 12 & 37 & 236.40 & -82 \\
\hline 23.069 & 303.129 & 313.099 & 45.94 & 128.4 & 2.537 & 242.70 & $6 E+02$ \\
\hline 66 & 303.077 & 313.072 & 45.81 & 12 & 2.537 & 247.00 & $6 E+02$ \\
\hline 80 & 303.061 & 313.071 & 45.89 & 128.4 & 2.537 & 245.40 & $.836 E+02$ \\
\hline 41 & 303.063 & 313.052 & 45.02 & 128.4 & 2.537 & 244.70 & $E+02$ \\
\hline 323 & .036 & .052 & 45.85 & 128.4 & 2.537 & 247.80 & $E+02$ \\
\hline 323 & .134 & 31 & 45 & 128.4 & 2. & 247.00 & $5 E+02$ \\
\hline 52 & & 31 & 45 & 12 & 2. & 247.00 & $E+02$ \\
\hline 323.036 & 303.147 & 31 & & & & 247.00 & 102 \\
\hline 323.034 & 303.146 & 313.090 & 45.51 & 128.4 & 2.537 & 247.00 & +02 \\
\hline 323.073 & 303.146 & 313.110 & 45.79 & 12 & 2.537 & 247.00 & $E+02$ \\
\hline 323.055 & 303.120 & 313.088 & 45.66 & 12 & 2.537 & 247.00 & +02 \\
\hline 323.008 & 303.099 & 313.054 & 46.18 & & 2.537 & 247.40 & $E+02$ \\
\hline רד & 303.131 & 313.111 & 45.81 & 12 & 2.537 & 247.40 & $E+02$ \\
\hline 323.16 & 303.125 & 313.146 & 45.68 & 128.4 & 2.537 & 247.40 & $.833 E+02$ \\
\hline
\end{tabular}


Toble 2. (cont.)

\begin{tabular}{|c|c|c|c|c|c|c|c|}
\hline $\begin{array}{l}\text { Thi } \\
(\mathrm{K})\end{array}$ & $\begin{array}{l}\text { TIo } \\
(K)\end{array}$ & $\begin{array}{c}\text { Tmeon } \\
(\mathrm{K})\end{array}$ & $\begin{array}{c}\text { Kdot } \\
\mathrm{mW} /(\mathrm{m} \cdot \mathrm{k})\end{array}$ & $\begin{array}{l}\text { AREA } \\
(\mathrm{cm})\end{array}$ & $\begin{array}{l}\text { DELX } \\
(\mathrm{cm})\end{array}$ & $\begin{array}{l}\text { DENSITY } \\
(\mathrm{kg} / \mathrm{m})\end{array}$ & $\begin{array}{l}\text { PRESSURE } \\
\text { (kPa) }\end{array}$ \\
\hline 343.207 & 323.167 & 333.187 & 47.97 & 128.4 & 2.539 & 247.40 & $.833 E+02$ \\
\hline 392.895 & 373.102 & 382.999 & 53.20 & 128.5 & 2.541 & 247.20 & $.833 E+02$ \\
\hline 393.149 & 373.124 & 383.137 & 53.18 & 128.5 & 2.541 & 247.20 & $.833 E+02$ \\
\hline 483.262 & 463.197 & 473.230 & 63.71 & 128.7 & 2.544 & 246.80 & $.833 E+02$ \\
\hline 591.999 & 553.118 & 572.559 & 75.03 & 128.9 & 2.549 & 246.40 & $.833 E+02$ \\
\hline 622.470 & 523.118 & 572.794 & 74.55 & 129.0 & 2.549 & 246.40 & $.833 E+02$ \\
\hline 671.898 & 493.743 & 582.821 & 75.56 & 129.1 & 2.549 & 246.30 & $.833 E+02$ \\
\hline 612.959 & 573.066 & 593.013 & 77.69 & 128.9 & 2.550 & 246.30 & $.833 E+02$ \\
\hline 633.178 & 593.161 & 613.170 & 80.13 & 129.0 & 2.551 & 246.20 & $.833 E+02$ \\
\hline 653.224 & 613.126 & 633.175 & 82.73 & 129.0 & 2.552 & 246.10 & $.833 E+02$ \\
\hline 673.212 & 633.088 & 653.150 & 85.26 & 129.1 & 2.553 & 246.00 & $.833 E+02$ \\
\hline 692.745 & 653.134 & 672.940 & 87.86 & 129.1 & 2.554 & 245.90 & $.833 E+02$ \\
\hline 712.13 & 672.899 & 692.518 & 91.82 & 129.1 & 2.555 & 245.80 & $.833 E+02$ \\
\hline 713.04 & 673.111 & 693.078 & 91.94 & 129.1 & 2.555 & 245.80 & $.833 E+02$ \\
\hline 763.37 & 728.645 & 746.009 & 96.89 & 129.2 & 2.557 & 245.60 & $.833 E+02$ \\
\hline 712.512 & 673.096 & 692.804 & 89.75 & 129.1 & 2.555 & 245.80 & $.833 E+62$ \\
\hline 343. & 323 & 3 & 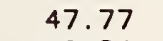 & 28.4 & .538 & 247.30 & +02 \\
\hline 363.22 & 3 & 0 & & 3.5 & 39 & .30 & +02 \\
\hline 383.227 & 363.06 & 148 & & 128.5 & 2.540 & 247.20 & +02 \\
\hline 403.24 & 383.24 & .243 & .34 & .5 & 541 & 247.10 & $E+02$ \\
\hline 423.17 & 383.0 & .096 & 5 & 6 & 41 & 247.10 & $E+02$ \\
\hline 443.12 & 383 & 6 & & & +1 & 247.00 & $E+02$ \\
\hline 463.15 & 383.20 & 9 & 5 & 7 & 42 & 247.00 & $E+02$ \\
\hline 482.96 & 383.21 & .087 & 29 & 7 & 42 & 246.90 & $E+02$ \\
\hline 502.89 & 38 & .030 & 0 & 7 & +3 & 246.90 & $E+02$ \\
\hline 522.95 & 38 & .076 & .52 & 8 & +3 & 246.90 & $.833 E+02$ \\
\hline 542.78 & 383.222 & .003 & .66 & .8 & +3 & 246.80 & $.833 E+02$ \\
\hline 562.7 & 383.205 & .978 & .79 & .8 & 44 & 246.80 & $.833 E+02$ \\
\hline 582.59 & 383.137 & 482.868 & 3.98 & .9 & 44 & 246.70 & $3 E+02$ \\
\hline 622.63 & 403.204 & .920 & 7.38 & 0 & 2.546 & 246.60 & $.833 E+02$ \\
\hline 662.26 & 402.976 & .622 & 2 & 0 & 2.547 & 246.50 & $.833 E+02$ \\
\hline 403.22 & 383.05 & 393.159 & .44 & 5 & 2.540 & 247.10 & $.833 E+02$ \\
\hline 423.29 & 403.2 & .295 & .74 & .6 & 2.541 & 247.00 & $.833 E+02$ \\
\hline 443.18 & 403.088 & 423.137 & 7.53 & .6 & 2.542 & 247.00 & $.833 E+02$ \\
\hline 483.279 & 443.028 & 463.154 & 62.03 & 128.7 & 2.543 & 246.80 & $833 E+02$ \\
\hline 523.22 & 481.285 & 502.253 & 66.51 & 128.8 & 2.545 & 246.70 & $.833 E+02$ \\
\hline 323.101 & 303.125 & 313.113 & 45.97 & 128.4 & 2.537 & 247.40 & $833 E+02$ \\
\hline 523.295 & 483.055 & 503.175 & 66.44 & 128.8 & 2.5 & 246.60 & $.833 E+02$ \\
\hline 563.18 & 522.13 & 542.659 & 70.91 & 128.8 & 2.5 & 246.50 & $.833 E+02$ \\
\hline 603.09 & 562.95 & 583.028 & 75.94 & 128.9 & 2.5 & 246.30 & $.833 E+02$ \\
\hline 642.82 & 602.91 & 622.872 & 80.46 & 129.0 & 2.5 & 246.20 & $3 E+02$ \\
\hline 682.82 & 642.97 & 662.897 & 85.13 & 129.1 & 2.553 & 246.00 & $.833 E+02$ \\
\hline 323.12 & 303.09 & 313.110 & 46.00 & 128.4 & & 247.50 & $833 E+02$ \\
\hline 323.14 & 303.157 & 313.149 & 46.25 & 128.4 & 2. & 247.50 & $.833 E+02$ \\
\hline 323. & 303.184 & 313.411 & 46.45 & 128.4 & 2.538 & 247.50 & $.833 E+02$ \\
\hline 583 & 563.17 & 573.16 & 75.53 & 128.9 & 2.549 & 246.40 & $.833 E+02$ \\
\hline 583. & 563.10 & 573.146 & 75.5 & $128 . \subseteq$ & 2.54 & 246.40 & $.833 E+02$ \\
\hline 332. & 312.336 & 322.34 & 46.98 & 128. & 2.53 & 247.40 & $833 E+02$ \\
\hline 333 & 313.150 & 323.150 & 46.98 & 128 & 2.538 & 247.40 & $833 E+02$ \\
\hline & 563.08 & 573. & 75.8 & 128. & 2.54 & 246.40 & $833 E+02$ \\
\hline & 568 & 578. & & & & 246.40 & $833 E+02$ \\
\hline 583.168 & 563.151 & 73 & 75.86 & 128 & 2.549 & 246.40 & $3 E+02$ \\
\hline
\end{tabular}


Toble 3. Thermal conductivity of o selected poir of fibrous oluminosilico insulotion boords with densities of 236 to $249 \mathrm{~kg} / \mathrm{m}^{3}$. ot meon temperotures of 313 and $693 \mathrm{~K}$. Meosurements were performed in oir ot pressures from 84 to $0.0047 \mathrm{kPo}$, using the NBS high-temperoture guorded hot plote.

\begin{tabular}{|c|c|c|c|c|c|}
\hline $\begin{array}{l}\text { Thigh } \\
(K)\end{array}$ & $\begin{array}{l}\text { Tlow } \\
(\mathrm{K})\end{array}$ & $\begin{array}{c}\text { Tmeon } \\
(\mathrm{K})\end{array}$ & $\begin{array}{c}\text { Kdot } \\
m W /(m \cdot k)\end{array}$ & $\begin{array}{c}\text { Pressure } \\
\text { (kPo) }\end{array}$ & $\begin{array}{l}\text { Percent } \\
\text { Deviotion }\end{array}$ \\
\hline $\begin{array}{l}323.042 \\
323.050 \\
323.050 \\
323.024 \\
323.069 \\
323.066 \\
323.080 \\
323.041 \\
323.068 \\
323.055 \\
323.027 \\
323.036 \\
323.034 \\
323.073 \\
323.055 \\
323.008 \\
323.090\end{array}$ & $\begin{array}{l}303.114 \\
303.127 \\
303.049 \\
303.095 \\
303.129 \\
303.077 \\
303.061 \\
303.063 \\
303.036 \\
303.134 \\
303.137 \\
303.147 \\
303.146 \\
303.146 \\
303.120 \\
303.099 \\
303.131\end{array}$ & $\begin{array}{l}313.078 \\
313.089 \\
313.050 \\
313.060 \\
313.099 \\
313.072 \\
313.071 \\
313.052 \\
313.052 \\
313.095 \\
313.082 \\
313.092 \\
313.090 \\
313.110 \\
313.088 \\
313.054 \\
313.111\end{array}$ & $\begin{array}{l}45.44 \\
45.63 \\
45.56 \\
45.29 \\
45.93 \\
45.81 \\
45.89 \\
45.02 \\
45.85 \\
45.77 \\
45.51 \\
45.47 \\
45.51 \\
45.79 \\
45.66 \\
46.18 \\
45.81\end{array}$ & $\begin{array}{l}.836 E+02 \\
.836 E+02 \\
.836 E+02 \\
.836 E+02 \\
.836 E+02 \\
.836 E+02 \\
.836 E+02 \\
.836 E+02 \\
.836 E+02 \\
.836 E+02 \\
.836 E+02 \\
.836 E+02 \\
.836 E+02 \\
.836 E+02 \\
.836 E+02 \\
.836 E+02 \\
.836 E+02\end{array}$ & $\begin{array}{r}-.70 \\
-.29 \\
-.45 \\
-1.04 \\
.38 \\
.11 \\
.28 \\
-1.63 \\
.19 \\
.02 \\
-.55 \\
-.64 \\
-.55 \\
.05 \\
-.22 \\
.92 \\
.10\end{array}$ \\
\hline $\begin{array}{l}323.063 \\
323.087 \\
323.119 \\
323.131 \\
323.121 \\
323.122 \\
323.150 \\
323.137 \\
323.089 \\
323.097\end{array}$ & $\begin{array}{l}303.066 \\
303.151 \\
303.148 \\
303.100 \\
303.175 \\
303.145 \\
303.146 \\
303.033 \\
303.117 \\
303.018\end{array}$ & $\begin{array}{l}313.065 \\
313.119 \\
313.134 \\
313.116 \\
313.148 \\
313.134 \\
313.148 \\
313.085 \\
313.103 \\
313.058\end{array}$ & $\begin{array}{r}45.54 \\
45.00 \\
43.03 \\
39.33 \\
35.20 \\
27.92 \\
22.38 \\
14.04 \\
8.04 \\
7.84\end{array}$ & $\begin{array}{l}.667 E+02 \\
.400 E+02 \\
.133 E+02 \\
.400 E+01 \\
.133 E+01 \\
.400 E+00 \\
.133 E+00 \\
.400 E-01 \\
.467 E-02 \\
.467 E-02\end{array}$ & $\begin{array}{r}.13 \\
.55 \\
1.05 \\
.77 \\
2.15 \\
-.63 \\
3.37 \\
-7.00 \\
3.22 \\
.74\end{array}$ \\
\hline $\begin{array}{l}323.167 \\
323.101 \\
323.121\end{array}$ & $\begin{array}{l}303.125 \\
303.125 \\
303.098\end{array}$ & $\begin{array}{l}313.146 \\
313.113 \\
313.110\end{array}$ & $\begin{array}{l}45.67 \\
45.97 \\
46.00\end{array}$ & $\begin{array}{l}.833 E+02 \\
.833 E+02 \\
.833 E+02\end{array}$ & $\begin{array}{r}-.18 \\
.47 \\
.53\end{array}$ \\
\hline
\end{tabular}

Stondard Deviotion $=1.69$

$\begin{array}{lllll}712.512 & 673.096 & 692.804 & 89.75 & .833 \mathrm{E}+02 \\ 712.522 & 673.042 & 692.782 & 89.52 & .666 \mathrm{E}+02 \\ 712.483 & 671.335 & 691.909 & 80.08 & .400 \mathrm{E}+01 \\ 713.057 & 673.109 & 693.083 & 56.10 & .173 \mathrm{E}+00\end{array}$




\begin{tabular}{|c|c|c|c|c|c|c|c|}
\hline \multirow{2}{*}{$\begin{array}{l}\text { Thi } \\
\text { (K) }\end{array}$} & \multicolumn{5}{|c|}{$\begin{array}{l}\text { Thermal conductivity of the selected poir } \\
\text { silica insulation boord with a density of } \\
\text { temperatures of } 313 \text { to } 692 \mathrm{~K} \text {. Meosurement } \\
\text { helium gos ot pressures of } 84 \text { to } 87 \mathrm{kPc} \\
\text { using the NBS high-temperature guarded hot }\end{array}$} & \multicolumn{2}{|c|}{$\begin{array}{l}\text { of fibrous alumino- } \\
247 \mathrm{~kg} / \mathrm{m}^{3} \text {, ot meor } \\
\text { s were performed ir } \\
\text { (630 to } 650 \text { Torr } \\
\text { plate. }\end{array}$} \\
\hline & $\begin{array}{l}T 10 \\
(K)\end{array}$ & $\begin{array}{c}\text { Tmean } \\
(K)\end{array}$ & $\begin{array}{c}K d a t \\
m W /(m \cdot K)\end{array}$ & $\begin{array}{l}\text { AREA } \\
\left(\mathrm{cm}^{2}\right)\end{array}$ & $\begin{array}{l}\text { DELX } \\
(\mathrm{cm})\end{array}$ & $\begin{array}{l}\text { DENSITY } \\
\left(\mathrm{kg} / \mathrm{m}^{3}\right)\end{array}$ & $\begin{array}{l}\text { PRESSURE } \\
(\mathrm{kPo})\end{array}$ \\
\hline & & & & & & & \\
\hline & & & & & & & \\
\hline 363 & 343.15 & 35 & 34 & $12 \varepsilon$ & 2.5 & & .846 \\
\hline 383. & 3.15 & & & 128 & 2.5 & 247.20 & $840 E$ \\
\hline 711.169 & 673.166 & 692.168 & 285.10 & 129.1 & 2.555 & 245.80 & $866 E+C$ \\
\hline
\end{tabular}


Table 5a. Thermal conductivity of eight different specimens of fibrous alumino-silica insulation board with densities of 236 to 249 $\mathrm{kg} / \mathrm{m}^{3}$, at a mean temperature of $313 \mathrm{~K}$. Measurements were performed in air at $84 \mathrm{kPa}$ using the NBS high-temperature guarded hot plate.

\begin{tabular}{|c|c|c|c|c|c|c|c|}
\hline $\begin{array}{l}\text { Th i } \\
(\mathrm{K})\end{array}$ & $\begin{array}{l}\text { TI } 0 \\
(K)\end{array}$ & $\begin{array}{c}\text { Tmean } \\
(K)\end{array}$ & $\begin{array}{c}K \operatorname{dot} \\
m W /(m \cdot k)\end{array}$ & $\begin{array}{l}\text { AREA } \\
\left(\mathrm{cm}^{2}\right)\end{array}$ & $\begin{array}{l}\text { DELX } \\
(\mathrm{cm})\end{array}$ & $\begin{array}{l}\text { DENS I TY } \\
\left(\mathrm{kg} / \mathrm{m}^{3}\right)\end{array}$ & $\begin{array}{l}\text { PRESSURE } \\
(\mathrm{kPo})\end{array}$ \\
\hline 23 & 303.114 & 313.078 & 44 & 128.4 & 2.537 & 242.70 & $.836 E+02$ \\
\hline & 303. & 313. & & 128.4 & & 249.40 & +02 \\
\hline 323. & 303.049 & 313.050 & 45. & 128.4 & & 244.70 & $E+82$ \\
\hline 323.024 & 303.095 & 313.060 & 45.29 & 128.4 & & 236.40 & $E+02$ \\
\hline 323.069 & 303.129 & 313.099 & 45.94 & 128.4 & & 242.70 & $E+02$ \\
\hline 323.066 & 303. & & 45.81 & 128.4 & & 247.00 & $=+02$ \\
\hline 323.080 & 30 & & 45. & 12 & & .40 & +02 \\
\hline 323.041 & 303.063 & 31 & 45 & & & .70 & +02 \\
\hline 323.068 & 303.036 & 31 & 45. & 12 & 2. & 247.80 & +02 \\
\hline 323.055 & 303.134 & 315 & 45. & 12 & 2. & 247.00 & -02 \\
\hline 323.02 & 303.137 & 313 & 45.51 & 12 & 2. & 247.00 & 02 \\
\hline 323.03 & 303.147 & 313. & 45. & .4 & 2. & 7.00 & 02 \\
\hline 323.03 & 303.146 & 313.8 & 45. & .4 & 2. & 7.00 & 02 \\
\hline 323.073 & 303.146 & 313.1 & 45.79 & 128.4 & 2.5 & 247.00 & -02 \\
\hline & 303.120 & 313.08 & 45.66 & 128.4 & 2.5 & 247.00 & $36 E+02$ \\
\hline & .099 & 313.054 & 46.18 & 128.4 & 2.537 & 247.40 & $36 E+02$ \\
\hline 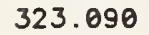 & 31 & 313.111 & 45.81 & 128.4 & 2.537 & 247.40 & 2 \\
\hline
\end{tabular}

Table 5b. Thermal conductivity of fibrous alumina-silica insulation board (round-robin material) with densities of 207 to 308 $\mathrm{kg} / \mathrm{m}^{3}$, at a mean temperature of $313 \mathrm{~K}$. Measurements were performed in oir ot $84 \mathrm{kPo}$ using the NBS high-temperoture guarded hot plate.

\begin{tabular}{|c|c|c|c|c|c|c|c|}
\hline $\begin{array}{l}\text { Thi } \\
(\mathrm{K})\end{array}$ & $\begin{array}{l}T 10 \\
(K)\end{array}$ & $\begin{array}{c}\text { Tmean } \\
(\mathrm{K})\end{array}$ & $\begin{array}{c}K \operatorname{dat} \\
\mathrm{mW} /(\mathrm{m} \cdot \mathrm{K})\end{array}$ & $\begin{array}{l}\text { AREA } \\
\left(\mathrm{cm}^{2}\right)\end{array}$ & $\begin{array}{l}\text { DELX } \\
(\mathrm{cm})\end{array}$ & $\begin{array}{l}\text { DENS I TY } \\
\left(\mathrm{kg} / \mathrm{m}^{3}\right)\end{array}$ & $\begin{array}{l}\text { PRESSURE } \\
(\mathrm{kPa})\end{array}$ \\
\hline 343.187 & 323.111 & 333.149 & 47.77 & 128.4 & 2.538 & 247.30 & $.833 E+02$ \\
\hline 343.207 & 323.167 & 333.187 & 47.97 & 128.4 & 2.539 & 247.40 & $.833 E+02$ \\
\hline 343.197 & 323.181 & 333.189 & 53.02 & 128.4 & 2.525 & 295.10 & $.853 E+02$ \\
\hline 343.108 & 323.179 & 333.144 & 53.22 & 128.4 & 2.512 & 295.80 & $.853 E+02$ \\
\hline 343.314 & 323.067 & 333.191 & 50.74 & 128.4 & 2.712 & 306.50 & $.833 E+02$ \\
\hline 343.376 & 323.117 & 333.247 & 50.62 & 128.4 & 2.662 & 307.70 & $.833 E+02$ \\
\hline 343.294 & 323.089 & 333.192 & 52.77 & 128.4 & 2.600 & 237.00 & $.833 E+02$ \\
\hline 343.399 & 323.157 & 333.278 & 50.94 & 128.4 & 2.628 & 221.40 & $E+02$ \\
\hline 343.316 & 323.063 & 333.190 & 49.26 & 128.4 & 2.557 & 236.40 & $E+02$ \\
\hline 343.232 & 323.107 & 333.170 & 54.39 & 128.4 & 2.628 & 225.70 & $E+02$ \\
\hline 343.468 & 323.028 & 333.248 & 52.77 & 128.4 & 2.611 & 223.40 & +02 \\
\hline 343.440 & 323.069 & 333.255 & 53.65 & 128.4 & 2. & 225.00 & +02 \\
\hline 343.169 & 323.126 & 333.148 & 53.36 & 128.4 & 2.611 & 220.50 & $E+02$ \\
\hline 343.154 & 323.113 & 333.134 & 46.84 & 128.4 & 2.600 & 220.10 & $.837 E+02$ \\
\hline 343.341 & 323.160 & 333.251 & 47.23 & 128.4 & 2.635 & 217.40 & $.833 E+02$ \\
\hline 343.179 & 323.082 & 333.131 & 46.46 & 128.4 & 2.649 & 207.20 & $.830 E+02$ \\
\hline 343.224 & 323.076 & 333.150 & 46.18 & 128.4 & 2.628 & 207.90 & $.833 E+02$ \\
\hline 343.506 & 323.168 & 333.337 & 48.03 & 128.4 & 2.651 & 214.20 & $.830 E+02$ \\
\hline 343.309 & 323.003 & 333.156 & 46.14 & 128.4 & 2.610 & 215.30 & $.829 E+02$ \\
\hline 343.438 & 323.185 & 333.312 & 46.32 & 128.4 & 2.626 & 209.00 & $.842 E+02$ \\
\hline 343.273 & 323.239 & 333.256 & 54.65 & 128.4 & 2.627 & 225.80 & $.840 E+02$ \\
\hline 343.112 & 323.192 & 333.152 & 54.31 & 128.4 & 2.627 & 225.80 & $.840 E+02$ \\
\hline 343.370 & 323.184 & 333.277 & 53.19 & 128.4 & 2.645 & 222.60 & $.840 E+02$ \\
\hline 343.190 & 323.143 & 333.167 & 53.03 & 128.4 & 2.645 & 222.60 & $.840 E+02$ \\
\hline
\end{tabular}




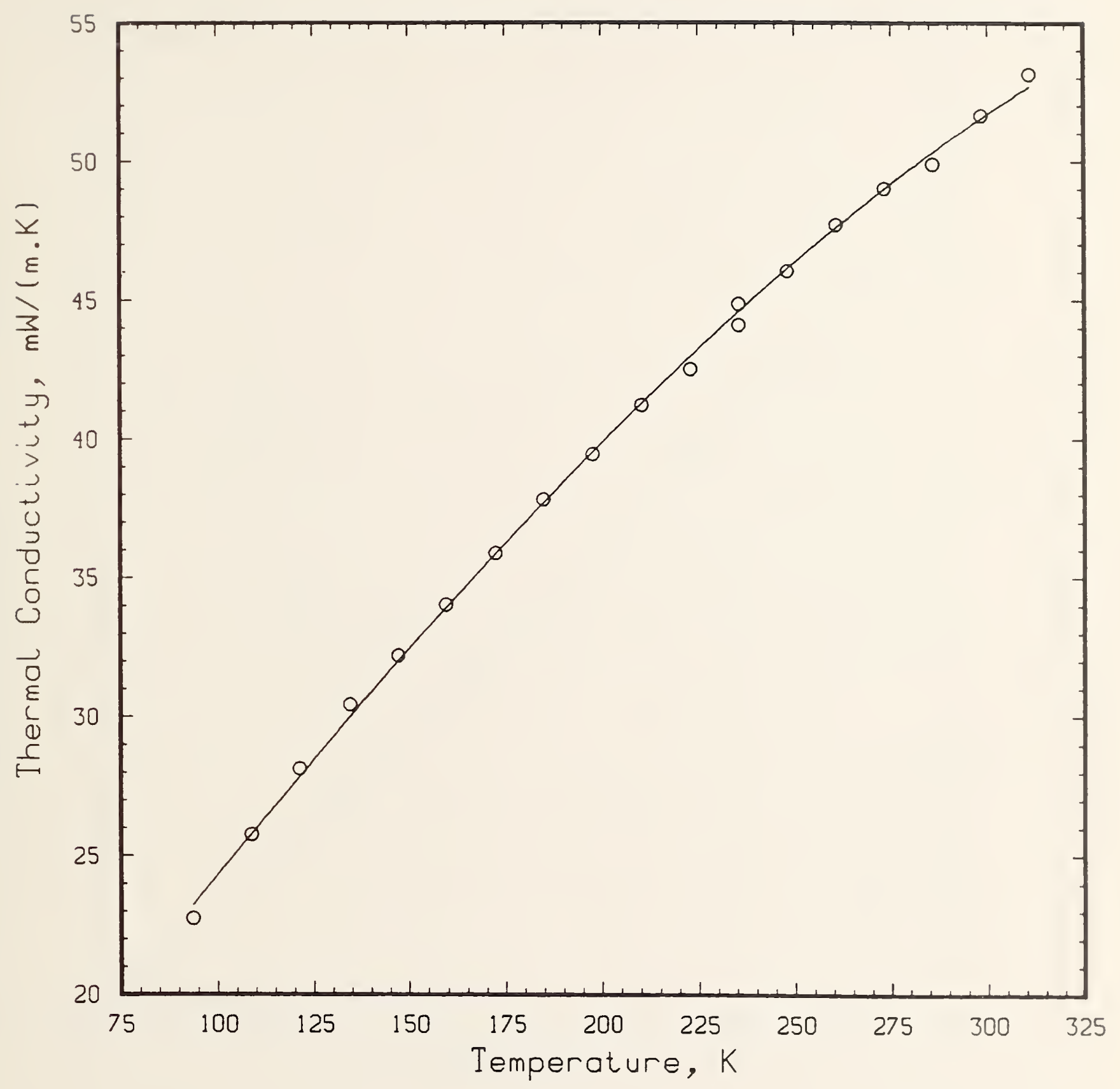

Figure 1. Thermal conductivity of a pair of fibrous alumina-silica insulation boards as measured by NBS/B, at mean temperatures of 93 to $311 \mathrm{~K}$ and at ambient atmospheric pressure of $83 \mathrm{kPa}$. Boards have a density of $259 \mathrm{~kg} / \mathrm{m}^{3}$. The solid line was calculated from eq(1). 


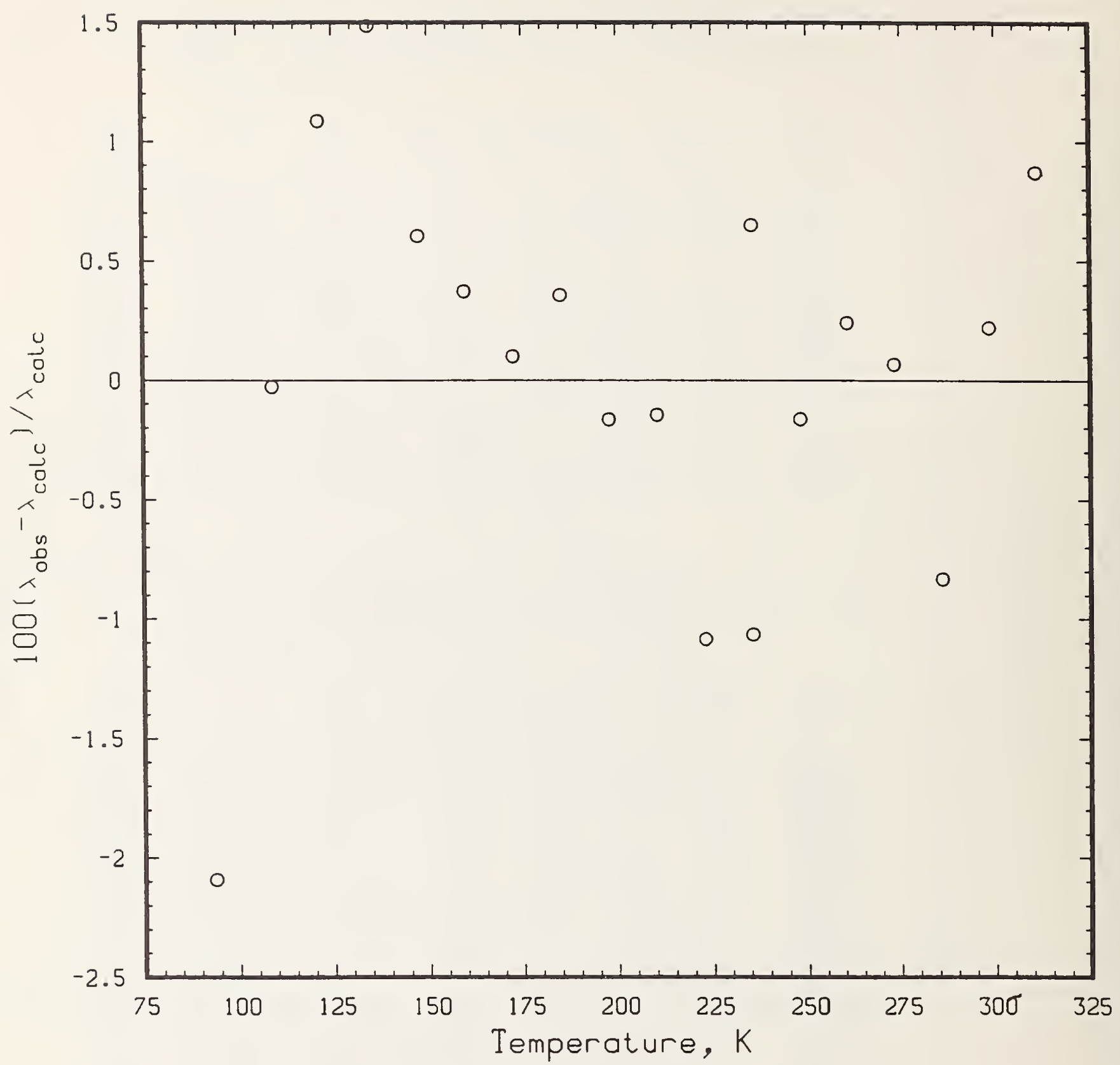

Figure 2. Deviations of the NBS low-temperature thermal conductivity data from eq(1). 


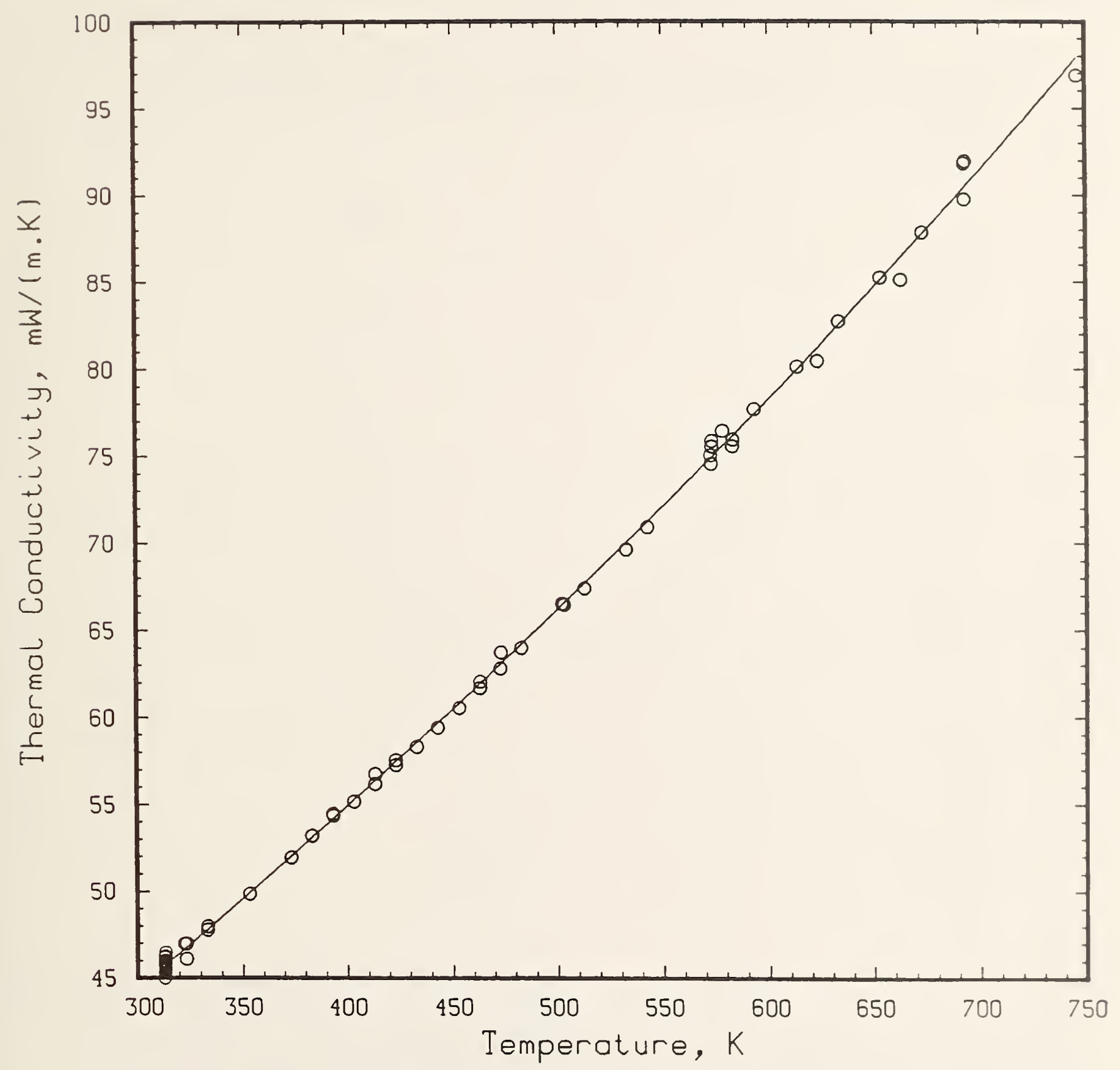

Figure 3. Thermal conductivity of a pair of fibrous alumina-silica insulation boards as measured by NBS/B, at mean temperatures of 313 to $746 \mathrm{~K}$ and at ambient atmospheric pressure of $83 \mathrm{kPa}$. Boards have a density of $247 \mathrm{~kg} / \mathrm{m}^{3}$. The solid line was calculated from eq(2). 


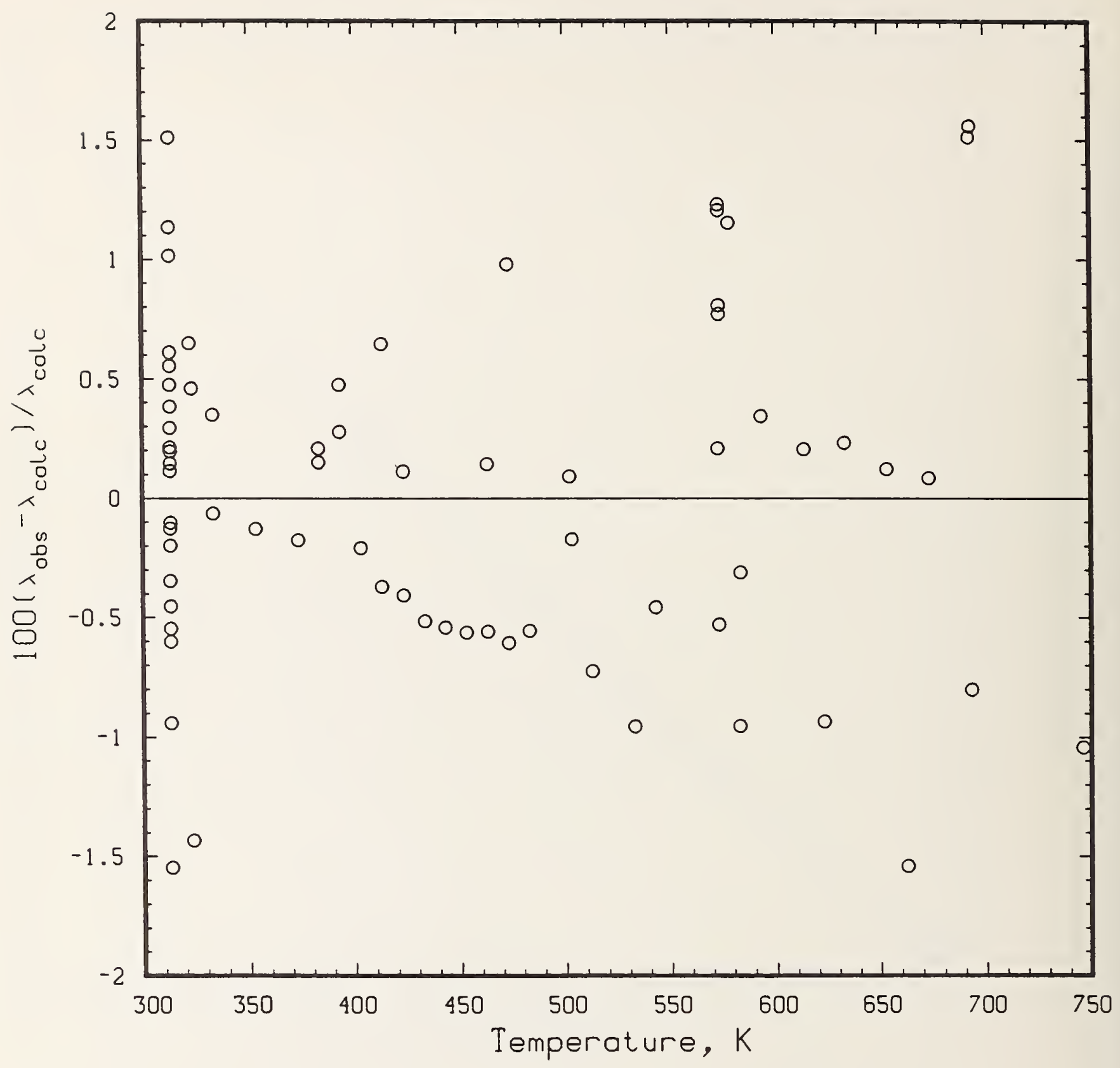

Figure 4. Deviations of the NBS high-temperature thermal conductivity data from eq(2). 


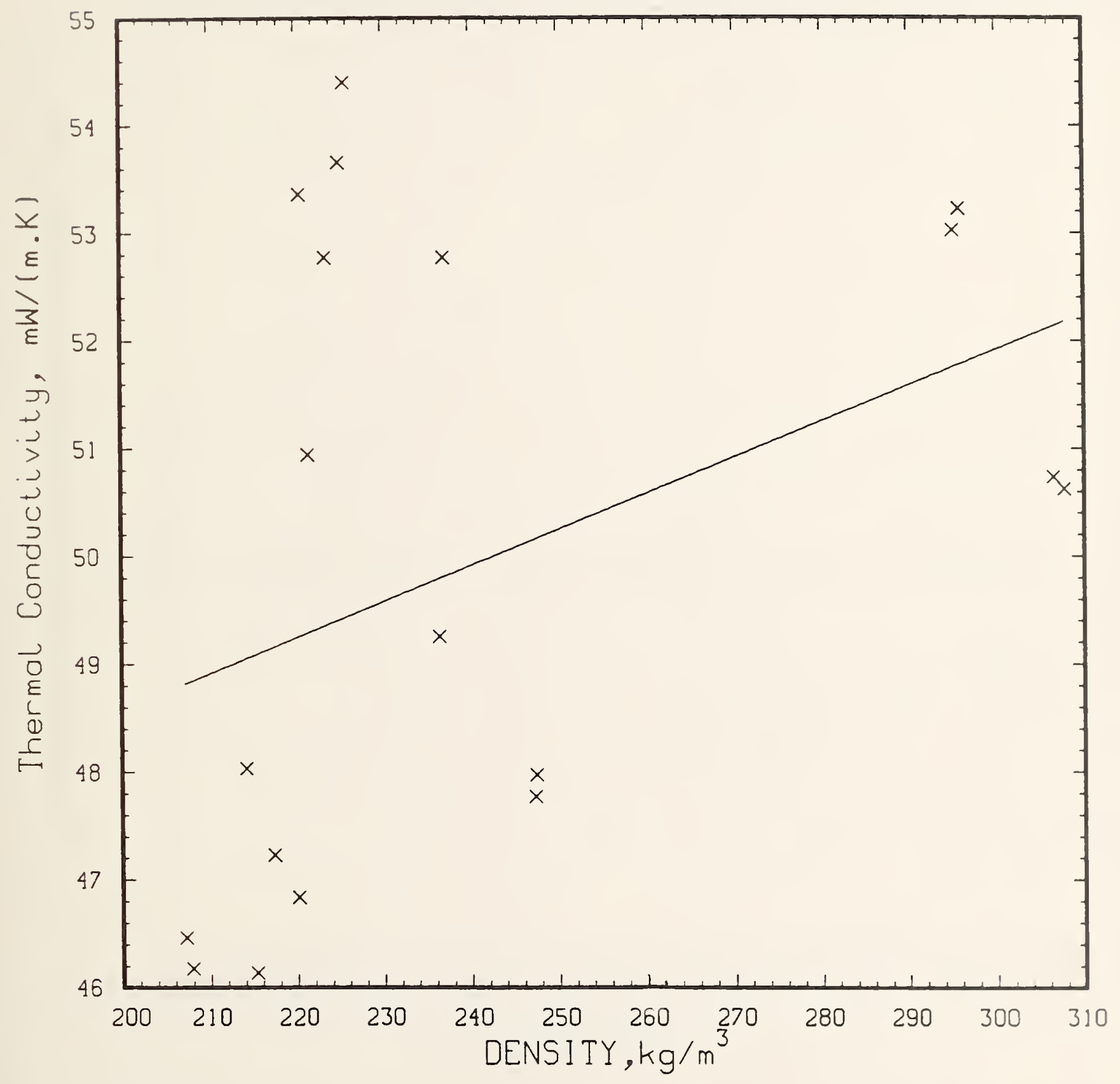

Figure 5. Thermal conductivity of fibrous alumina-silica insulation boards as measured by NBS/B, at a mean temperature of $333 \mathrm{~K}$ and at ambient atmospheric pressure of $84 \mathrm{kPa}$. The solid line was calculated from eq( 3$)$. 


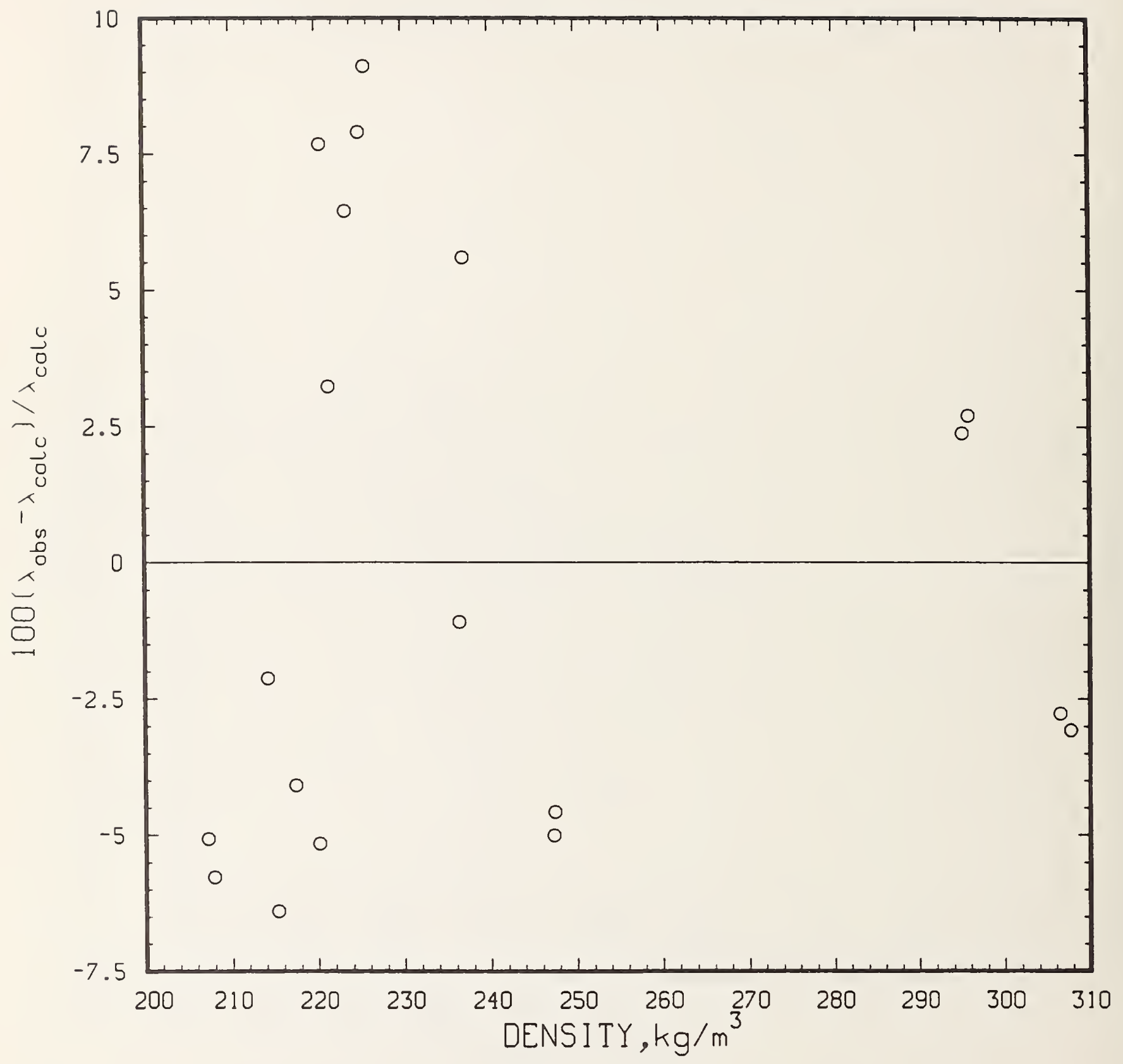

Figure 6. Deviations of the NBS thermal conductivity data from eq(3). 


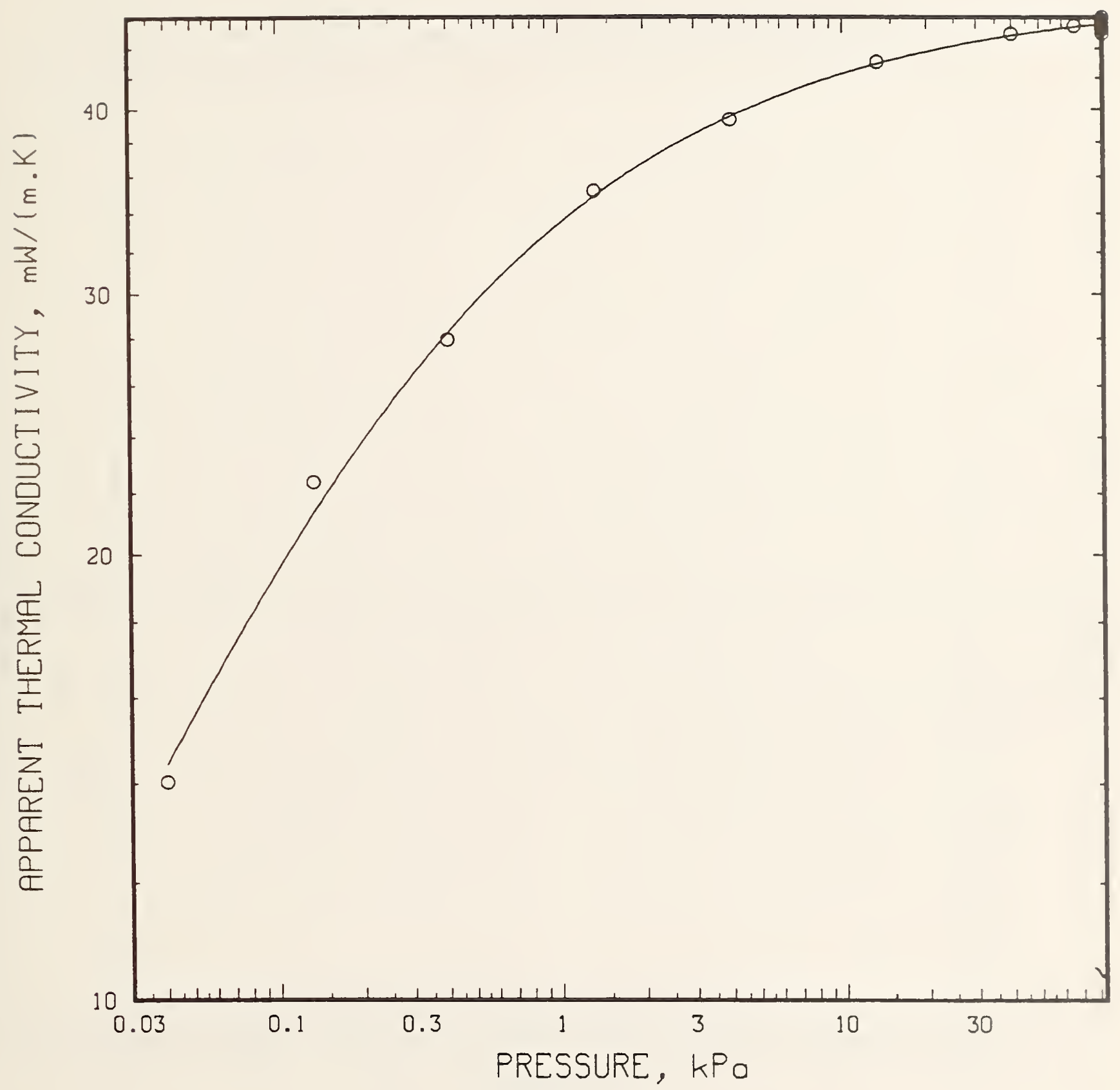

Figure 7. Thermal conductivity of fibrous alumina-silica insulation boards as measured by NBS/B, at a mean temperature of $313 \mathrm{~K}$. The boards have a density of $247 \mathrm{~kg} / \mathrm{m}^{3}$. The solid line was calculated from eq(4) with ko $=5.75, A=778$. $P_{0}=0.054 \mathrm{kPa}$ and $\mathrm{n}=0.5$. 


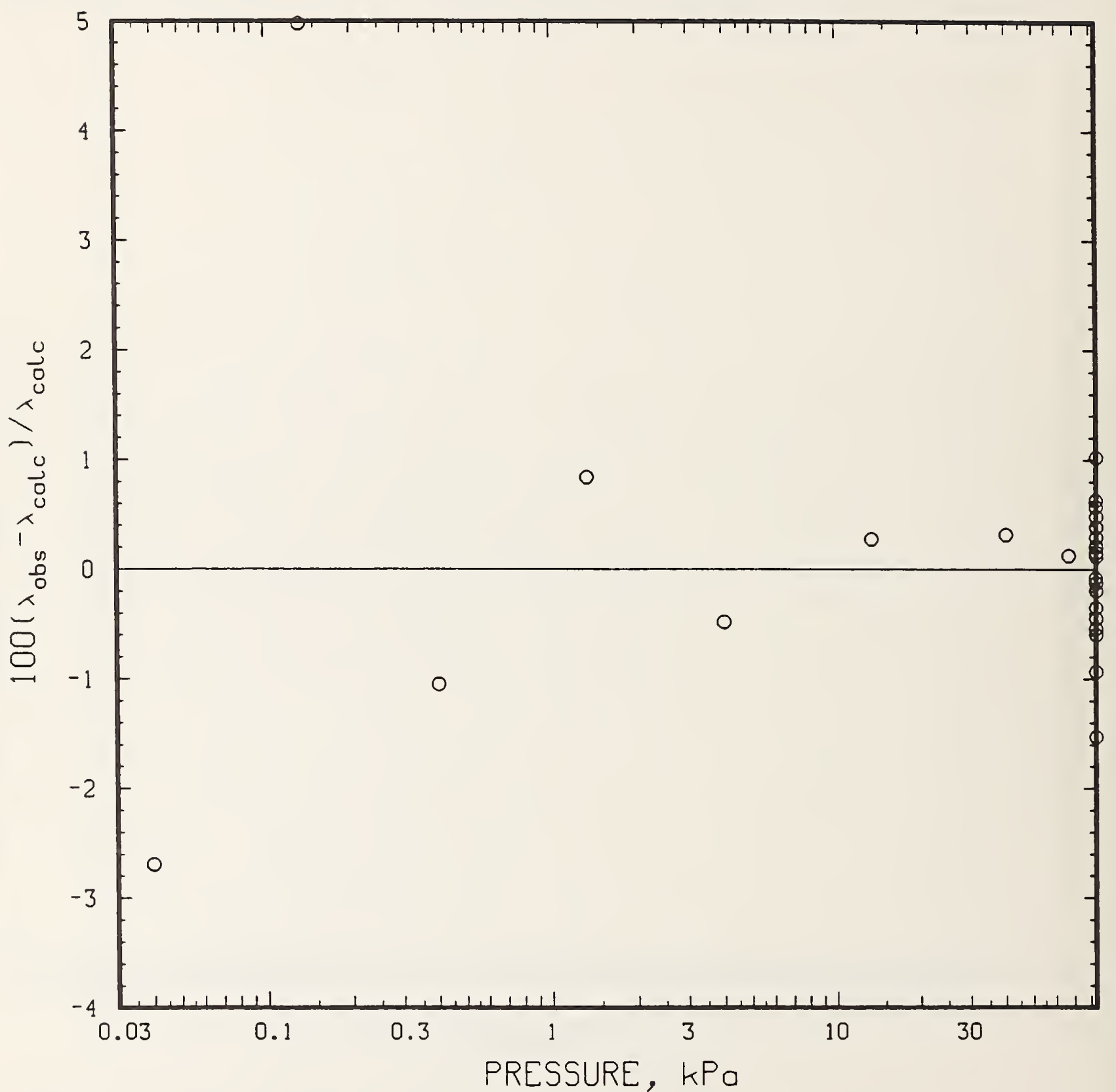

Figure 8. Deviations of the NBS thermal conductivity data from eq(4). 


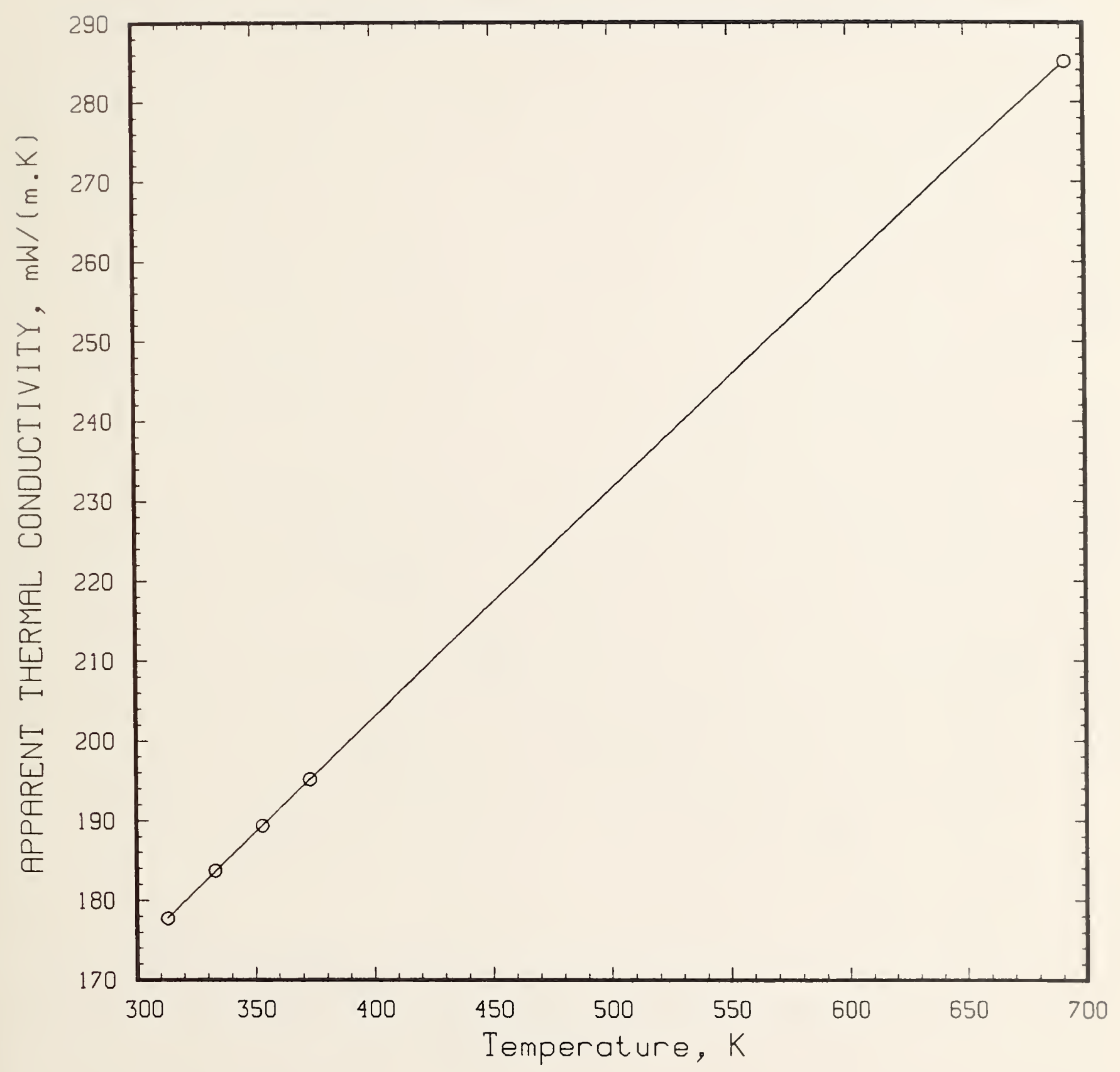

Figure 9. Thermal conductivity of fibrous alumina-silica insulation boards as measured by NBS/B, in an environment of pure helium gas. The board density is $247 \mathrm{~kg} / \mathrm{m}^{3}$. The solid line was calculated from eq(5). 


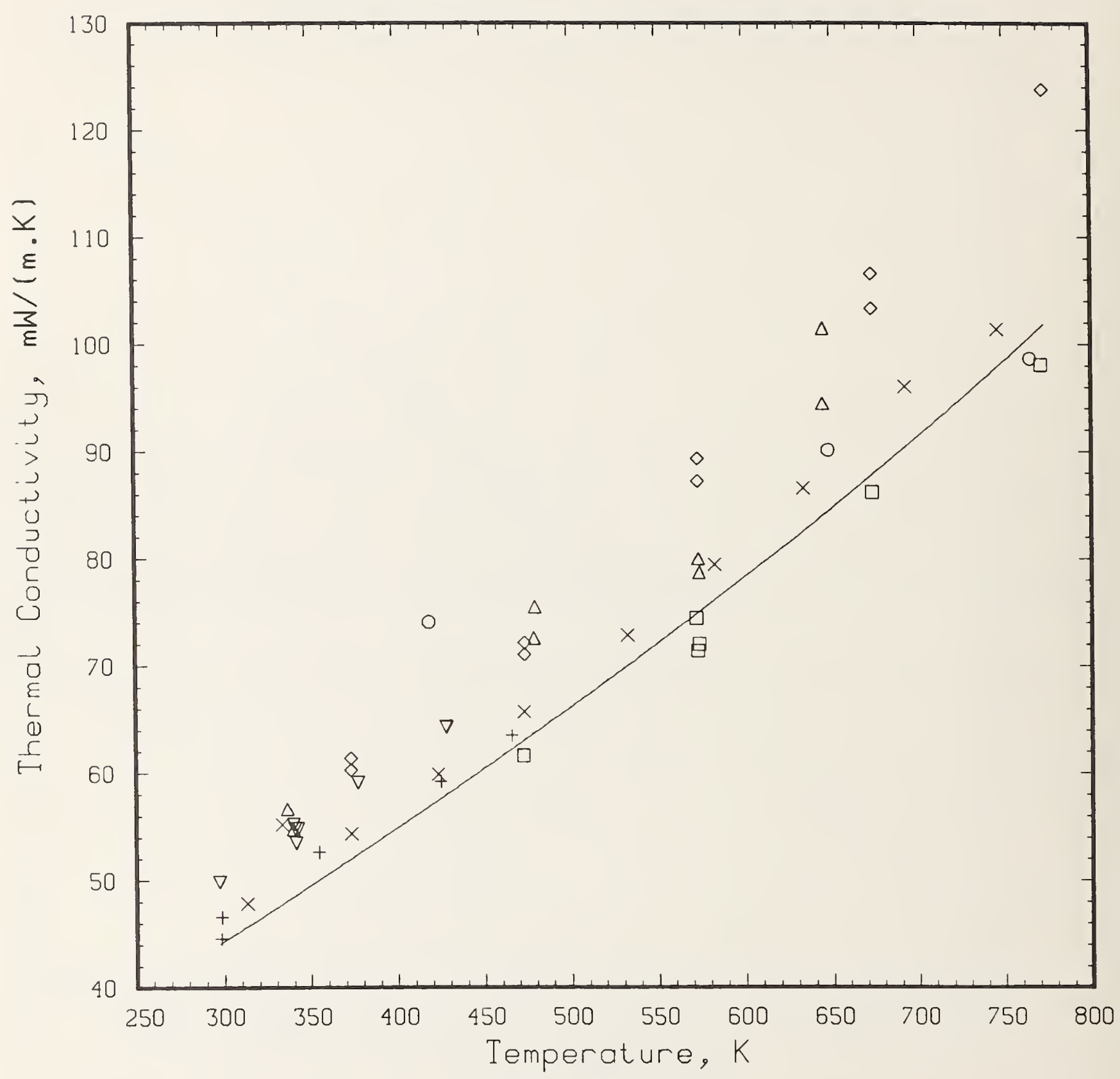

Figure 10. Round-robin measurements, by seven participating labs including NBS/B, of thermal conductivity of fibrous alumina-silica insulation boards, at the local ambient atmospheric pressure of each participating laboratory. The board density is $238 \mathrm{~kg} / \mathrm{m}^{3}$. The solid line is calculated from eq (1). 


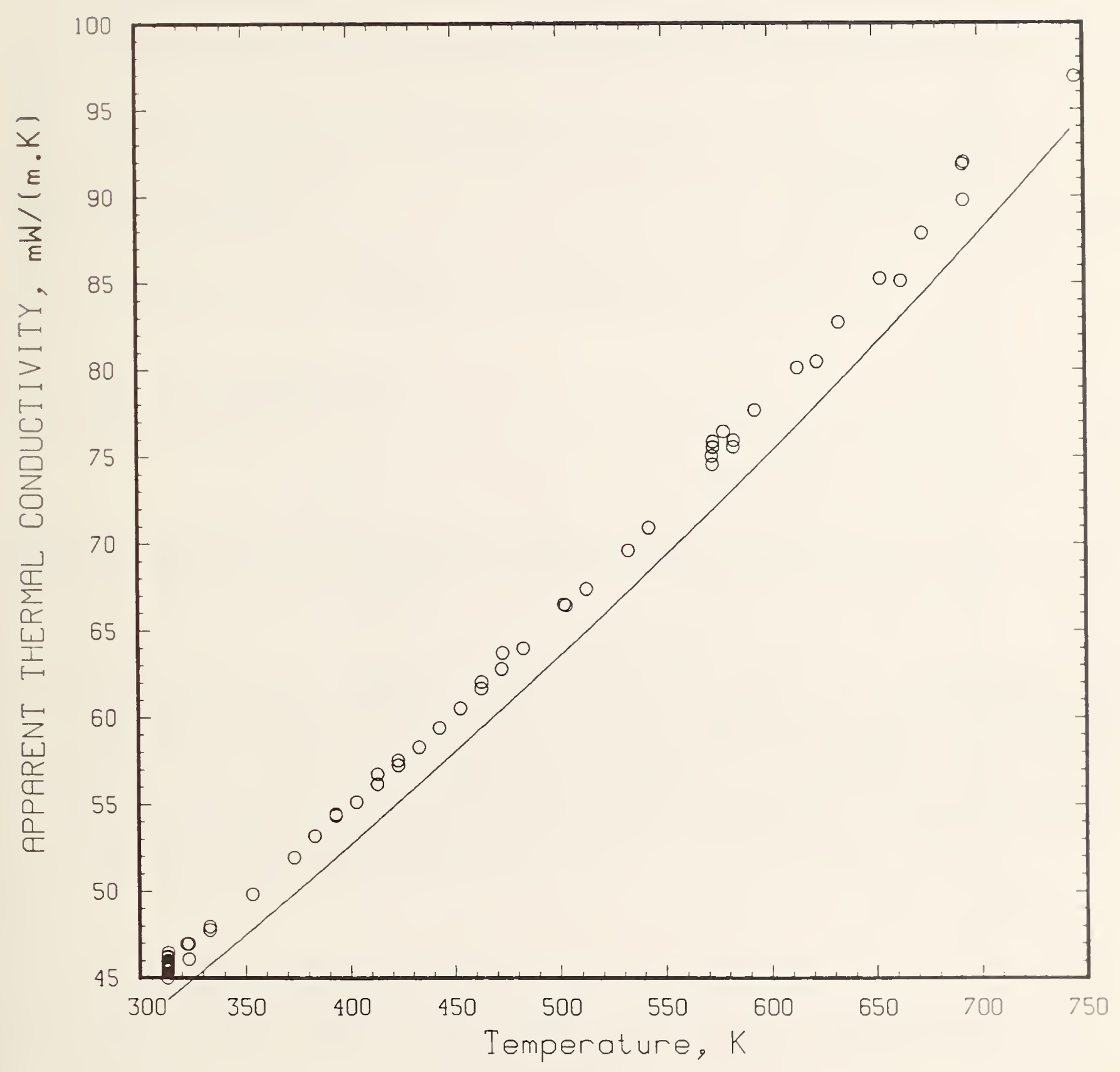

Figure 11. Thermal conductivity of fibrous alumina-silica insulation boards, as measured by the producer (solid line) at a pressure of $84 \mathrm{kPa}$, for a board with a density of $244 \mathrm{~kg} / \mathrm{m}^{3}$. The solid line is given by eq(6). Data points shown are NBS data for a different specimen with a dersity of $247 \mathrm{~kg} / \mathrm{m}^{3}$. 


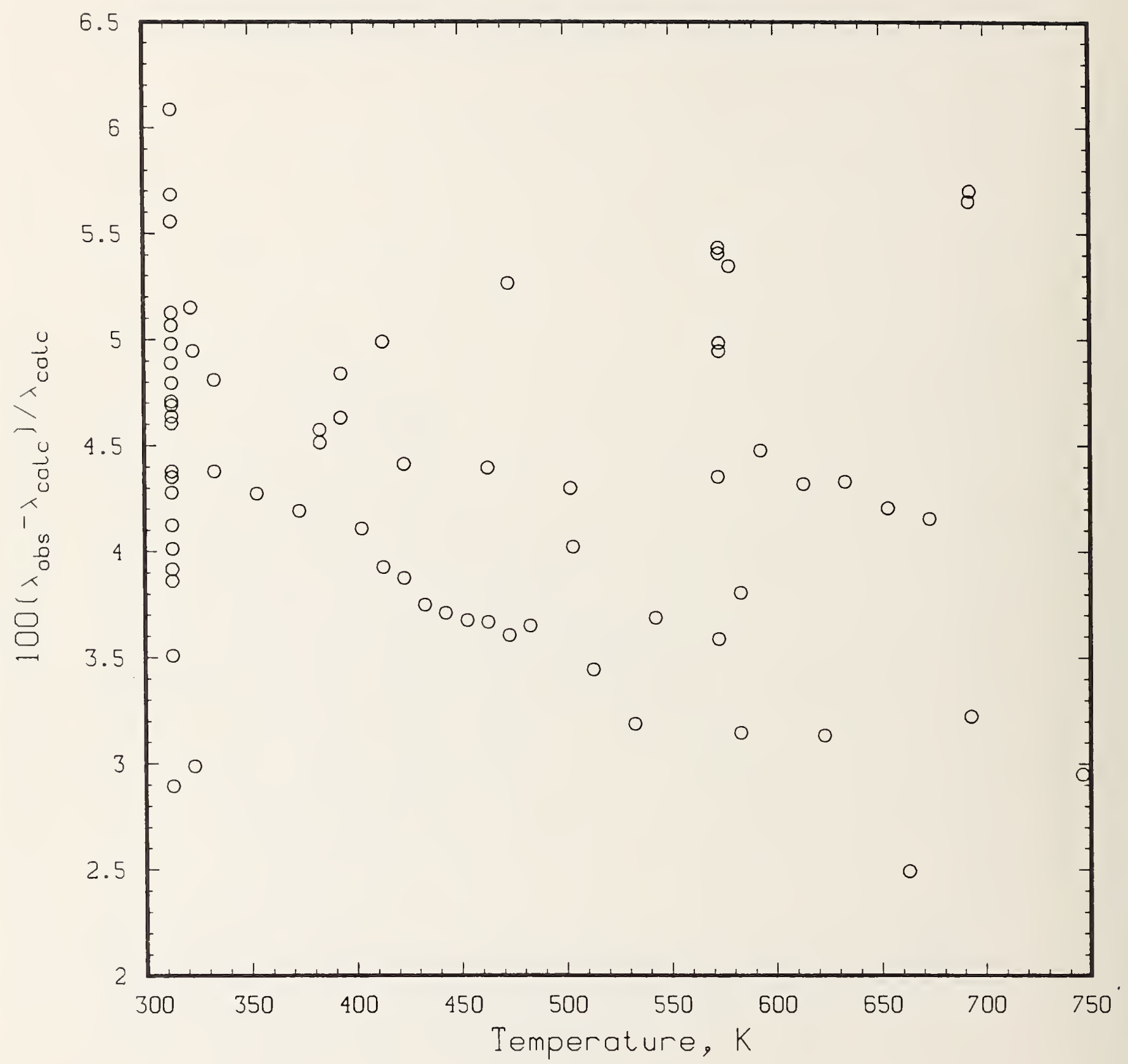

Figure 12. Deviations of the NBS/B thermal conductivity data from the producer's data, eq (6). 
4. TITLE AND SUBTITLE

Fibrous Alumina-Silica Insulation Board as a Candidate Standard Reference Material of Thermal Resistance

5. $A \cup T H O R(S)$

Hust, Jerome G. and Smith, David R.

6. PERFORMING ORGANIZATION (If joint or other than NBS, see instructions)

NATIONAL BUREAU OF STANDARDS

DEPARTMENT OF COMMERCE

WASHINGTON, D.C. 20234

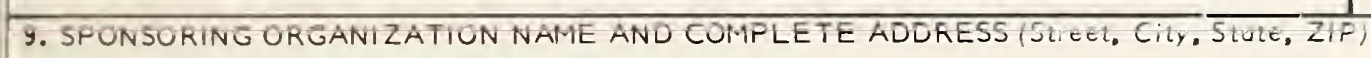

7. Contracd Grant No. ORNL/ IA-21428

8. Type of Report \& Period Covered

Dept. of Energy

P.0. Box $X$

Oak Ridge National Laboratory

Oak Ridge, TN 37830

10. SUPPLEMENTARY NOTES

Document describes a computer program; SF-185, FIPS Software Summary, is attached.

11. ABSTRACT (A 200-word or less factual summary of most significant information. If document includes a significant bibliography or literature survey. mention it here)

Measurements of apparent thermal conductivity are reported in order to provide the basis for certifying fibrous alumina-silica insulation board as a Standard Reference Material (SRM) of thermal resistance. These data encompass ranges of temperature from 93 to $746 \mathrm{~K}$, densities from 207 to $308 \mathrm{~kg} / \mathrm{m}^{3}$, and fill-gas pressures from roughing-pump vacuum to atmospheric pressure, in environments of both air and helium. Detailed analyses and intercomparisons of previously published data are given.

12. KEY WORDS (Six to twelve éntries; alphabetical order; capitalize only proper names; and separaze key words by semicolons/ alumina-silica board; apparent thermal conductivity; density; pressure; Standard Reference Material; temperature; themal insulation; themal resistance.

13. AVAILABILITY

[X] Unlimited

$\square$ For Official Distribution. Do Not Release to NTIS

$\square$ Order From Superintendent of Documents, U.S. Government Printing Office, Washington. D.C. 20402.

14. NO. OF PRINTED PAGES 36

15. Price

X] Order From National Technical Information Service (NTIS), Springfield, VA. 22161 




